JGR Oceans

\author{
RESEARCH ARTICLE \\ 10.1029/2019JC016006 \\ Key Points: \\ - Spray autonomous underwater \\ gliders completed more than \\ two years of sustained sampling \\ near Cape Hatteras, NC \\ - Export of Middle Atlantic Bight \\ shelf waters near Cape Hatteras is \\ event-driven \\ - Characteristics of export events vary \\ substantially
}

Supporting Information:

- Supporting Information S1

- Movie S1

Correspondence to:

R. E. Todd,

rtodd@whoi.edu

Citation:

Todd, R. E. (2020). Export of Middle Atlantic Bight shelf waters near Cape Hatteras from two years of underwater glider observations. Journal of Geophysical Research: Oceans, 125, e2019JC016006. https://doi.org/10. 1029/2019JC016006

Received 23 DEC 2019

Accepted 15 MAR 2020

Accepted article online 17 MAR 2020

(C)2020. American Geophysical Union. All Rights Reserved.

\section{Export of Middle Atlantic Bight Shelf Waters Near Cape Hatteras From Two Years of Underwater Glider Observations}

\author{
Robert E. Todd ${ }^{1}$ (D) \\ ${ }^{1}$ Woods Hole Oceanographic Institution, Woods Hole, MA, USA
}

\begin{abstract}
Equatorward flow of Middle Atlantic Bight (MAB) shelf waters meets poleward flowing South Atlantic Bight shelf waters over the continental shelf near Cape Hatteras, NC, leading to net export of shelf waters into the deep ocean. This export occurs in close proximity to the Gulf Stream, which separates from the continental margin near Cape Hatteras. Observations from sustained underwater glider surveys of the outer continental shelf and slope north of Cape Hatteras from spring 2017 to spring 2019 are used to examine the mean and variability of MAB shelf water export in the region. The $0.3 \mathrm{~Sv}\left(1 \mathrm{~Sv}=10^{6}\right.$ $\mathrm{m}^{3} \mathrm{~s}^{-1}$ ) time-mean export of MAB shelf water south of $37^{\circ} \mathrm{N}$ was dominated by discrete export events; $50 \%$ of export occurred during the $17 \%$ of the time during which transport was more than 1 standard deviation above the mean. These events typically occurred in late spring and summer of both years when equatorward flow into the region peaked. Export of MAB shelf water was correlated with equatorward flow into the region, which was itself correlated with the density gradient across the continental shelf break. Observations during specific time periods that capture extrema in MAB shelf water export are examined to highlight the variability in shelf-deep ocean exchange scenarios in the Hatteras region. These include near-surface export driven by hurricanes, subsurface export below the northern edge of the Gulf Stream, and a multi-month near-cessation of export.
\end{abstract}

Plain Language Summary The coastal ocean circulation near Cape Hatteras, NC, is characterized by convergence of waters from the Middle Atlantic Bight (MAB) and South Atlantic Bight. The resulting shelf water export takes place under the influence of forcing by variable winds (including passing tropical cyclones) and variable Gulf Stream strength and position just seaward of the continental shelf. As part of a program to understand the physical processes controlling exchange between the continental shelf and deep ocean at Cape Hatteras, autonomous underwater gliders surveyed the outer continental shelf and upper continental slope north of Cape Hatteras from spring 2017 through spring 2019. These observations are used to characterize the mean and annual cycle of the hydrography and circulation in the region and to examine temporal variability in the export of MAB shelf waters from the shelf. Time-mean MAB shelf water export of $0.3 \mathrm{~Sv}\left(1 \mathrm{~Sv}=10^{6} \mathrm{~m}^{3} \mathrm{~s}^{-1}\right)$ was dominated by export events in late spring and summer of both years. Variability in shelf water export was associated with variability in equatorward flow into the region and density gradients across the continental shelf break. To demonstrate the variety of export-related events in the region, several specific time periods are examined.

\section{Introduction}

Near Cape Hatteras, NC, along-shore flow over the continental shelf is typically convergent. Relatively cool and fresh waters from the Middle Atlantic Bight (MAB; Cape Cod, MA, to Cape Hatteras) flow equatorward as warmer, saltier waters from the South Atlantic Bight (Cape Canaveral, FL, to Cape Hatteras) flow poleward (Figure 1a). This along-shelf convergence, combined with the narrowing and shoaling of the continental shelf toward Cape Hatteras, requires net export of shelf waters into the deep ocean in the vicinity of Cape Hatteras. Just seaward of the continental shelf, the poleward flowing Gulf Stream separates from the continental margin at Cape Hatteras (Figure 1a) as it meets the equatorward flow of the Slope Sea (e.g., Csanady \& Hamilton, 1988; Flagg et al., 2006) and Deep Western Boundary Current, the latter of which descends to pass under the Gulf Stream at Cape Hatteras (Andres et al., 2018; Pickart \& Smethie, 1993). Though the mean circulation near Cape Hatteras is characterized by export of shelf waters, the regional circulation is highly variable, in part due to forcing by Gulf Stream variability (e.g., Churchill \& Berger, 1998; 

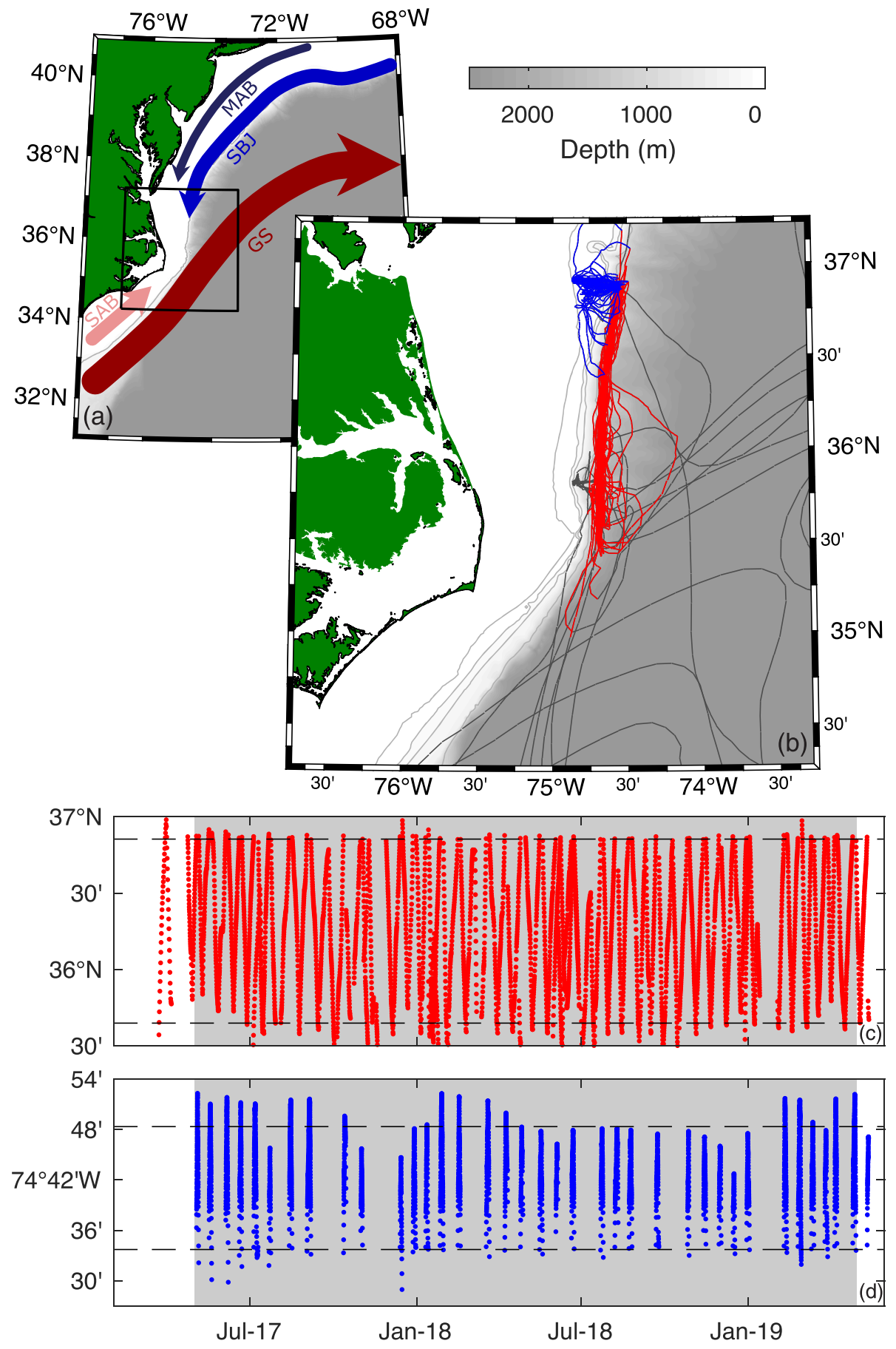

Figure 1. (a) Map of the U.S. mid-Atlantic coast with the Cape Hatteras region outlined in black and shown in detail in (b); the gray 200-m isobath marks the shelf break. Schematic surface currents shown entering the region are the Gulf Stream (GS, dark red), the shelfbreak jet (SBJ, blue), flow over the Middle Atlantic Bight shelf (MAB, dark blue), and flow over the South Atlantic Bight shelf (SAB, pink). (b) Spray glider trajectories in the vicinity of Cape Hatteras during PEACH with surveys along the slope transect in red, surveys along the shelf transect in blue, and all other trajectories in dark gray. Gray contours are the 50-, 100-, 200-, and 1,000-m isobaths. (c) Time-latitude plot of sampling along the slope transect. (d) Time-longitude plot of sampling along the shelf transect. In (c) and (d), gray shading represents the period of 1 May 2017 to 30 April 2019 used for fitting of means and annual cycles, and horizontal dashed lines indicate the spatial limits for fitting means and annual cycles. 
Churchill \& Gawarkiewicz, 2012; Gawarkiewicz \& Linder, 2006; Savidge \& Bane, 2001) and variable atmospheric forcing, including passage of major storms (e.g., Dirks et al., 1988; Glenn et al., 2016); bidirectional exchange between the continental shelf and deep ocean has been observed (e.g., Churchill \& Cornillon, 1991; Gawarkiewicz et al., 1996).

Since Cape Hatteras marks the endpoint for MAB circulation, which itself is the last stage of the 5,000-km-long coastal current system originating in the Labrador Sea (Chapman \& Beardsley, 1989), export of MAB shelf waters near Cape Hatteras has been the focus of numerous studies. Observations of cool, fresh waters along the edge of the Gulf Stream (e.g., Church, 1937; Fisher, 1972; Ford et al., 1952; Kupferman \& Garfield, 1977), often referred to as "Ford Water," have long indicated that MAB shelf waters are exported near Cape Hatteras and then entrained into the Gulf Stream as it flows into the open North Atlantic. Three large field programs previously examined shelf-deep ocean exchange at Cape Hatteras: a Minerals Management Service-sponsored program in 1992-1994 (MMS study; Berger et al., 1995), the "Ocean Margins Program" in 1996 (OMP; Verity et al., 2002), and the "Frontal Interactions Near Cape Hatteras" program in 2004-2005 (FINCH; Gawarkiewicz et al., 2008; Savidge \& Austin, 2007). The MMS and OMP studies relied on extensive moored and shipboard sampling, while FINCH used shipboard ADCP and towed, undulating CTD surveys. From these studies, two broad categories of MAB shelf water export emerged (see the schematic by Churchill \& Gawarkiewicz, 2012, their Figure 12): (1) seaward diversion of the MAB shelfbreak jet, which may occur gradually or abruptly depending, in particular, on shelfbreak jet location relative to the Gulf Stream (Churchill \& Berger, 1998; Gawarkiewicz \& Linder, 2006) and (2) seaward transport of mid-to-inner shelf waters (Churchill \& Gawarkiewicz, 2012).

A particular challenge in prior studies has been quantifying the volume of MAB shelf water exported near Cape Hatteras. Estimates of along-shelf transport in the MAB are more common. Combining available observations spanning several decades with a simple model, Lentz (2008) showed that the mean equatorward transport shoreward of the shelf break decreases monotonically from $0.64 \mathrm{~Sv}$ at Cape Cod to $0.09 \mathrm{~Sv}$ at $36^{\circ} 15^{\prime} \mathrm{N}$. The 15 - to $20-\mathrm{km}$-wide shelfbreak frontal jet (Figure 1a) typically carries $0.2-0.3 \mathrm{~Sv}$ equatorward (Linder \& Gawarkiewicz, 1998) until detaching from the shelf break and turning offshore as it approaches Cape Hatteras (Gawarkiewicz \& Linder, 2006; Churchill \& Berger, 1998). The location of shelfbreak jet detachment has been shown to vary between $35^{\circ} 30^{\prime} \mathrm{N}$ and at least $37^{\circ} \mathrm{N}$ (Gawarkiewicz \& Linder, 2006). Savidge and Bane (2001) inferred cross-shore transport of $0.24 \pm 0.19 \mathrm{~Sv}$ (mean \pm standard deviation) from differences in along-shore transport through cross-shelf mooring lines near $36^{\circ} 15^{\prime} \mathrm{N}$ and $35^{\circ} 30^{\prime} \mathrm{N}$. The small spatial and temporal scales associated with the shelfbreak frontal circulation in the MAB, typically 10-40 km and about 1 day (Gawarkiewicz et al., 2004; He et al., 2010; Todd et al., 2013), and the shifting locations of export (e.g., Gawarkiewicz et al., 1996; Gawarkiewicz \& Linder, 2006) have made quantification of MAB shelf water export challenging from prior observations.

The "Processes driving Exchange At Cape Hatteras (PEACH)" program was designed to elucidate the dynamics governing exchange of waters between the shelf and deep ocean in the vicinity of Cape Hatteras. The PEACH field program combined fixed, mobile, and shore-based observing platforms to observe circulation over the continental shelf and slope and within the Gulf Stream during 2017-2019. Realistic numerical modeling, including data assimilation, is a central part of $\mathrm{PEACH}$ and is expected to allow for examination of dynamics that cannot be diagnosed directly from the observations.

This analysis focuses on observations collected by autonomous underwater gliders (Rudnick, 2016; Testor et al., 2019) sampling along the upper continental slope and across the outer continental shelf for PEACH. Section 2 describes the observations and the methods used to produce gridded, low-pass-filtered versions of the observations. Section 3 discusses the results of the analysis, first characterizing the mean and annual cycles of the hydrography and circulation (sections 3.1 and 3.2) and then presenting the gridded, low-pass-filtered product (section 3.3). We then focus on export of MAB shelf waters by examining temporal variability of shelf water export over a 2-year period (section 3.4.1) and considering case studies of times with large and small export of shelf water (section 3.4.2). Section 4 summarizes the results and implications.

\section{Observations and Methods}

\subsection{Spray Glider Observations}

For more than two years from spring 2017 through spring 2019, Spray autonomous underwater gliders (Rudnick et al., 2016; Sherman et al., 2001) surveyed along the upper continental slope ("slope transect"; 

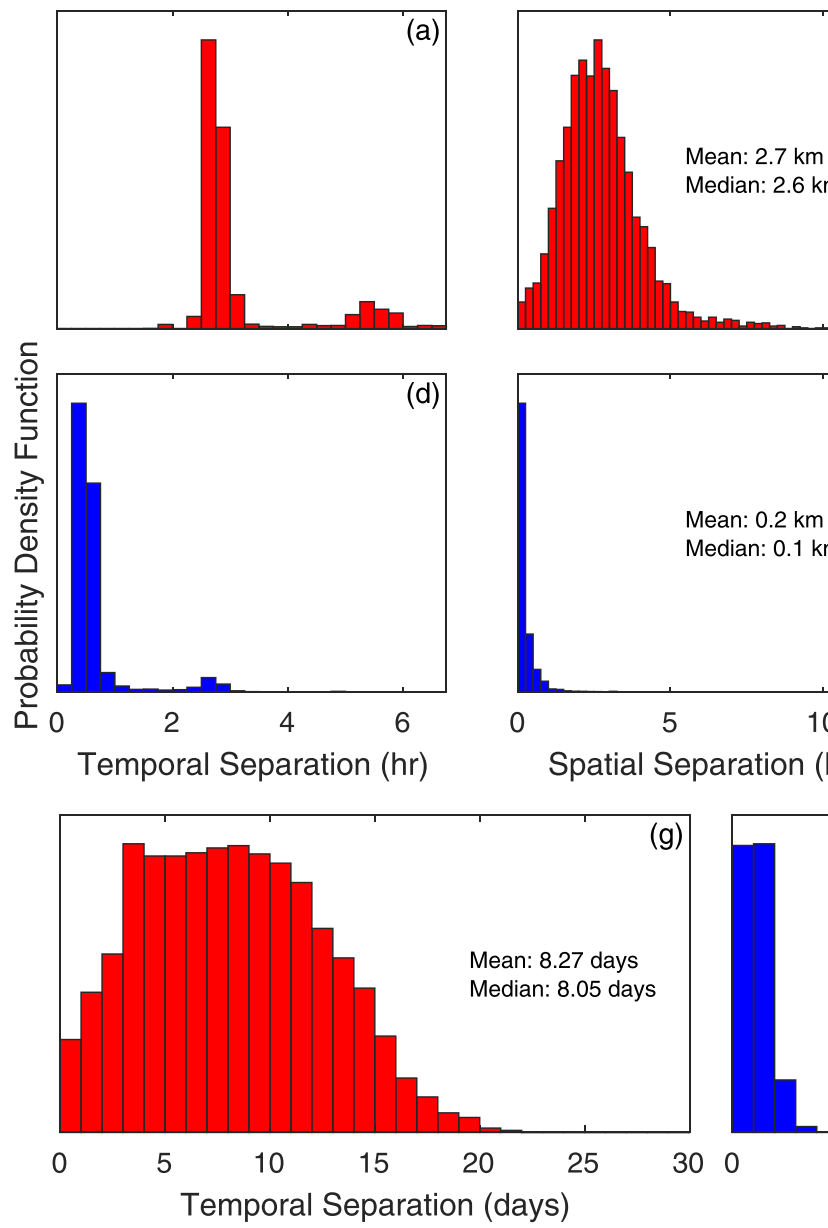
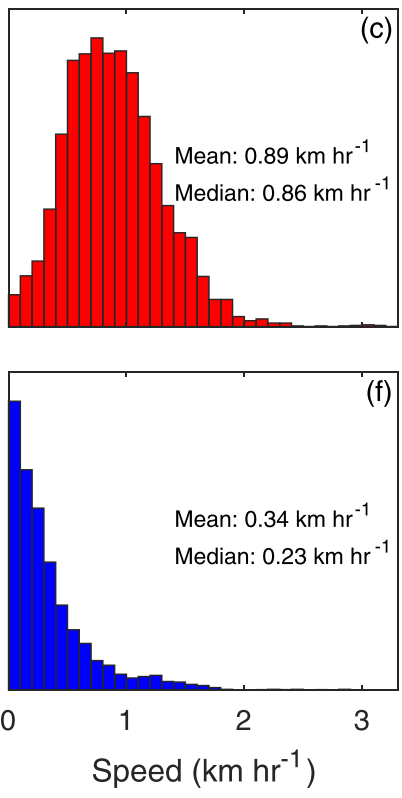

(f)

(h)

Figure 2. Probability density functions of Spray glider sampling metrics during PEACH and related statistics. (a-f) Dive-to-dive temporal (a,d) and spatial (b,e) separation and speed over ground $(c, f)$ along $(a-c)$ the slope transect and (d-f) the shelf transect. Spatial separation and speed are along the nominal transects. (g-h) Transect-to-transect temporal separation along the slope $(\mathrm{g})$ and shelf $(\mathrm{h})$ transects.

Figure 1b, red) and across the outer continental shelf ("shelf transect"; Figure 1b, blue) north of Cape Hatteras during seven back-to-back missions as part of PEACH. Spray gliders for PEACH were typically deployed and recovered just beyond the shelf break near $35^{\circ} 50^{\prime} \mathrm{N}, 74^{\circ} 50^{\prime} \mathrm{W}$ using small vessels based in Wanchese, NC, except for the first glider deployed in April 2017, which was deployed from R/V Neil Armstrong just offshore of the shelf break near $38^{\circ} 22^{\prime} \mathrm{N}$. Spray gliders tasked with surveying the Gulf Stream (Figure 1b, gray tracks; Todd, 2017; Todd \& Locke-Wynne, 2017; Todd et al., 2018) provided additional occupations of the slope transect before and during PEACH.

The slope transect extended roughly along the 1,500-m isobath between about $36^{\circ} 50^{\prime} \mathrm{N}$ and the northern edge of the Gulf Stream (Figure 1b, red), which varied in position (Figure 1c). Gliders were piloted southward until progress stalled due to adverse Gulf Stream currents, then turned northward along the transect. Gliders typically sampled to a maximum depth of $500 \mathrm{~m}$ every $2.5 \mathrm{hr}$ along the slope transect, unless encountering strong, adverse currents, in which case maximum depth was temporarily increased to 1,000 m with $5.5 \mathrm{hr}$ profile intervals (Figure 2a). Typical spacing between profiles was about $3 \mathrm{~km}$ (Figure 2b) with speed over the ground averaging just under $1 \mathrm{~km} \mathrm{hr}^{-1}$ or about $0.25 \mathrm{~m} \mathrm{~s}^{-1}$ (Figure 2c). In total, 107 occupations of the slope transect are available from March 2017 through May 2019 (Figure 1c) with a typical temporal separation between repeat occupations of about 8 days (Figure $2 \mathrm{~g}$ ).

Upon reaching the northern end of the slope transect, gliders usually proceeded westward across the outer continental shelf with a goal of reaching the $50-\mathrm{m}$ isobath. In relatively shallow water, currents (both tidal and subtidal) often impeded glider navigation, leading to more scattered sampling (Figure 1b, blue). Gliders 


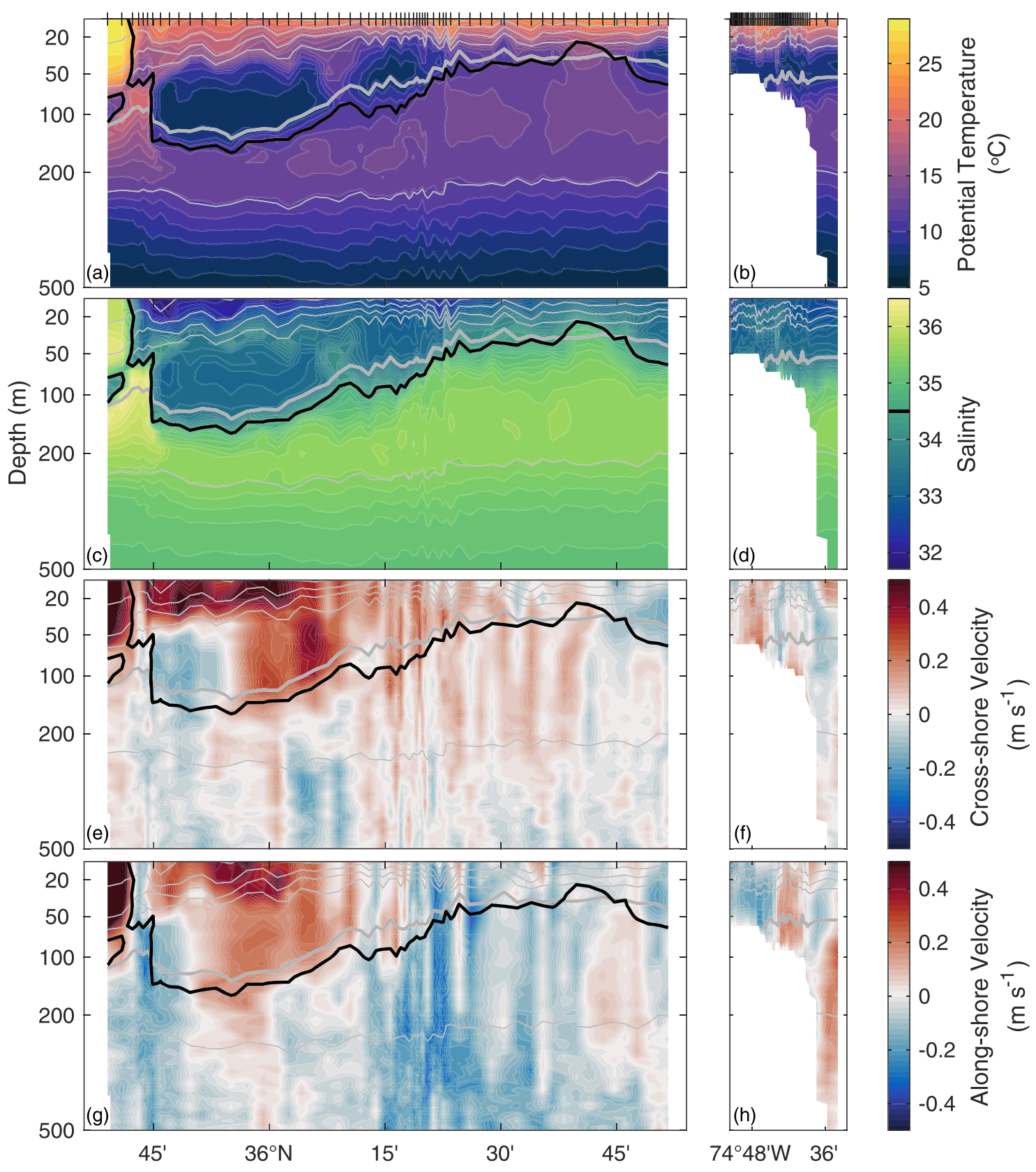

Figure 3. Example Spray glider transects along the slope transect (left) and shelf transect (right) during August 2017. Transects of (a-b) potential temperature, (c-d) salinity, (e-f) cross-shore velocity, and ( $\mathrm{g}-\mathrm{h}$ ) along-shore velocity are shown in color with isopycnals in gray with a contour interval of $1 \mathrm{~kg} \mathrm{~m}^{-3}$ and the $26 \mathrm{~kg} \mathrm{~m}^{-3}$ bold. The black contour is the 34.5 isohaline, which is used to delimit MAB shelf waters. Tick marks on the upper-most axes denote locations of individual profiles. Seaward transport of MAB shelf water through the slope transect shown here is shown by a star in Figure 12a.

sampled to within a few meters of the seafloor in water shallower than $500 \mathrm{~m}$. Temporal and horizontal spacing between profiles over the shallow continental shelf were typically less than $1 \mathrm{hr}$ and less than $0.2 \mathrm{~km}$, respectively (Figures $2 \mathrm{~d}$ and 2e); glider speed over the ground slowed in shallow water due to adverse currents and less efficient flight (Figure 2f). A total of 73 occupations of the shelf transect are available between May 2017 and May 2019 (Figure 1d). Temporal separation between successive transects is bimodal with 1-2 days between paired inbound and outbound transects and about 2 weeks (i.e., twice the time to occupy the slope transect) between successive pairs of shelf transects (Figure $2 \mathrm{~h}$ ).

Each glider was equipped with a pumped Sea-Bird 41CP CTD, a 1-MHz Nortek AD2CP Doppler current profiler, and a Seapoint chlorophyll fluorometer, each sampling during the ascending portion of each glider 

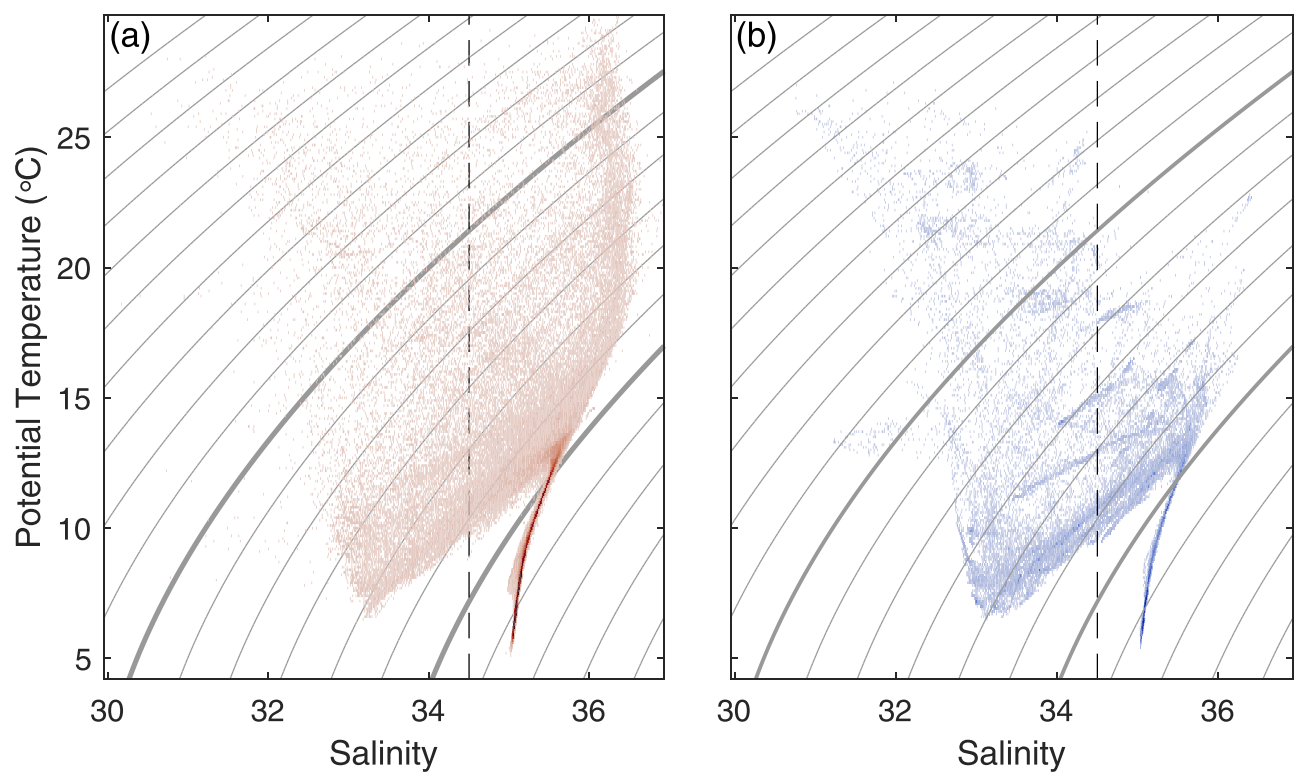

Figure 4. Joint probability density functions of salinity and potential temperature in the upper $500 \mathrm{~m}$ along the (a) slope and (b) shelf transects. Observations binned to $10-\mathrm{m}$ vertical resolution from all profiles along each transect (Figure $1 b$, red and blue) are included. Axes limits represent the range of observed salinities and potential temperatures. Gray contours show potential density with a contour interval of $0.5 \mathrm{~kg} \mathrm{~m}^{-3}$ and the 24.0 and $27.0 \mathrm{~kg} \mathrm{~m}^{-3}$ isopycnals bold. The black dashed line is the 34.5 isohaline; MAB waters are taken to be all waters with salinity less than 34.5.

dive. Following standard quality control and postprocessing for Spray gliders (e.g., Rudnick et al., 2017, 2018; Todd et al., 2017), profiles of potential temperature, salinity, potential density, absolute horizontal currents, $1-\mathrm{MHz}$ acoustic backscatter, and chlorophyll fluorescence are available at 10-m vertical resolution for each glider dive. For two missions, AD2CP data from some profiles are missing due to a firmware issue; the missing velocity profiles are filled by linear interpolation in time for the purpose of computing transports below. Three missions additionally included Sea-Bird 63 dissolved oxygen sensors. Our focus here will be on the physical variables; chlorophyll fluorescence, acoustic backscatter, and dissolved oxygen are not discussed further. Along-shore currents are taken to be positive toward $5.1^{\circ}$, the true bearing between the southernmost and northernmost waypoints set along the slope transect; cross-shore currents are taken to be positive offshore.

Examples of observations along the slope and shelf transects are shown in Figure 3. Along the slope transect, noteworthy features include warm, salty water flowing northeastward in the Gulf Stream at the southern end of the transect (Figures 3a, 3c, 3e, and 3g); inner shelf waters with salinities less than 32 near the surface (Figure 3c); and cool, fresh MAB Cold Pool waters (Houghton et al., 1982) in a subsurface anticyclone just north of the Gulf Stream (Figures 3a, 3c, and 3e). The summertime shelf transect shows the typical temperature stratification above the MAB Cold Pool (Figure 3b), but a distinct shelfbreak front and associated shelfbreak jet are difficult to distinguish in this particular transect (Figures 3b, 3d, 3f, and 3h).

Over the 2-year sampling period, gliders encountered a wide range of water mass properties (Figure 4), as expected for the Hatteras region (e.g., Churchill \& Gawarkiewicz, 2014; Savidge et al., 2013). The widest range of temperatures and salinities is found along the slope transect (Figure 4a), where extremes of the potential temperature-salinity $(\theta-S)$ distribution above $27 \mathrm{~kg} \mathrm{~m}^{-3}$ are characteristic of Gulf Stream waters (salinities $>36$ ), MAB Cold Pool Waters (salinities $\sim 33, \sim 7^{\circ} \mathrm{C}$ ), and inner shelf waters (salinitIes $<32$ ). Along the shelf transect, the range of shelf water properties is similar, but high salinity Gulf Stream waters are rarely observed (Figure 4b). At densities greater than $27 \mathrm{~kg} \mathrm{~m}^{-3}$ (i.e., deeper than the continental shelf), the $\theta-S$ distributions are tightly clustered along mixing lines; the slightly fresher lobe in the $\theta$-S distribution between 7 and $10^{\circ} \mathrm{C}$ results from mixing between the most commonly observed upper Labrador Sea Water and fresher Antarctic Intermediate Waters. The tight $\theta-S$ distribution at depth indicates good CTD cross-calibration between glider missions. 


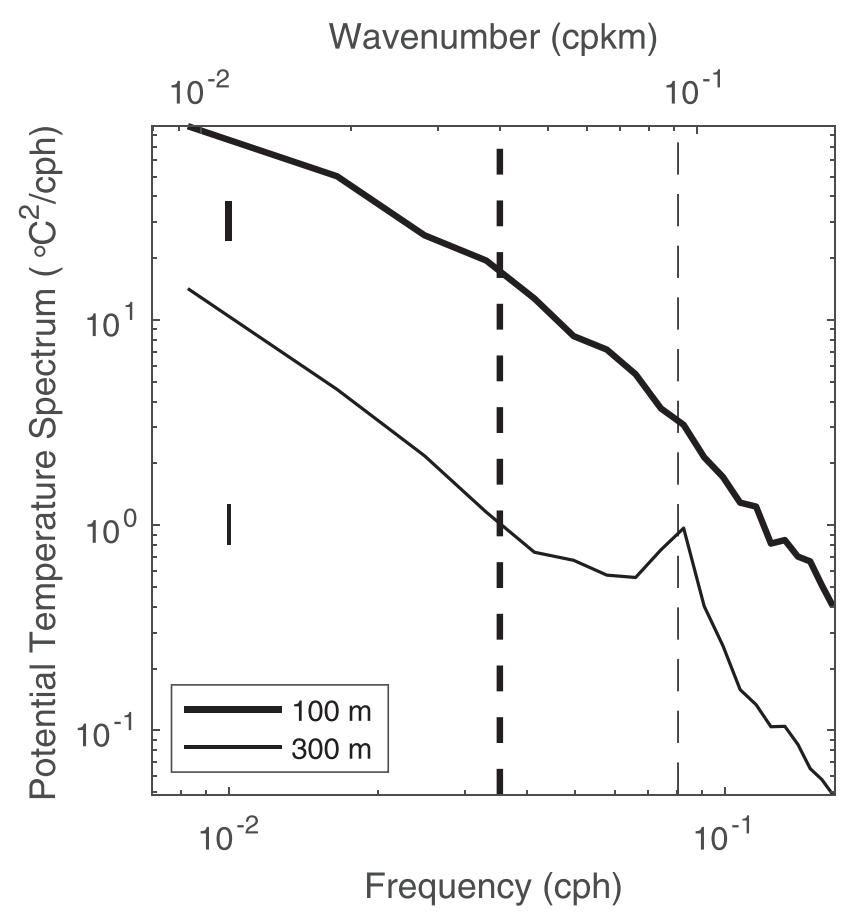

Figure 5. Frequency spectra of potential temperature at depths of $100 \mathrm{~m}$ (thick) and $300 \mathrm{~m}$ (thin) along the slope transect. Spectra are normalized such that the integrals equal the total variance of the data. Along the upper axis, equivalent wavenumber is shown assuming a constant glider speed of $0.88 \mathrm{~km} \mathrm{hr}^{-1}$ (Figure 2c). Dashed vertical lines indicate the $M_{2}$ tidal frequency (thin dashed) and the cutoff wavenumber of $0.04 \mathrm{cpkm}$ used for analysis (thick dashed); $95 \%$ confidence intervals are indicated by the short vertical segments at $10^{-2} \mathrm{cph}$.
Since gliders are moving platforms, their observations capture a combination of spatial and temporal variability (Rudnick \& Cole, 2011). In particular, the high-frequency heaving of surfaces by internal waves can manifest as variability at small spatial scales along level surfaces. By examining spectra of the observations, it is possible to estimate the horizontal scales that are contaminated by temporal variability and so to determine the effective spatial resolution of the observations (Rudnick \& Cole, 2011; Rudnick et al., 2017).

To understand the horizontal scales resolved by the PEACH Spray glider observations, we consider the spectra of temperature at depths of 100 and $300 \mathrm{~m}$ along the slope transect (Figure 5). To estimate these spectra, we interpolate irregularly spaced observations to a regular temporal grid with resolution of $1 \mathrm{hr}$, average frequency spectra for every possible 5-day segment of interpolated observations within each transect, then average these frequency spectra across transects. Errors on the resulting spectra are estimated by assuming that there are twice as many resulting degrees of freedom as there are distinct 5-day or longer transects; the averaging of spectral estimates from all possible 5-day segments within distinct transects serves to include all observations but is not considered to increase the number of degrees of freedom.

The spectra are characteristically red, as expected, with nearly an order of magnitude stronger variance at $100 \mathrm{~m}$ than at $300 \mathrm{~m}$. A significant semidiurnal peak is apparent near 0.08 cycles per hour (cph) at $300 \mathrm{~m}$, but not at $100 \mathrm{~m}$. The region near Cape Hatteras is a local minimum in $M_{2}$ tidal variability (Moody et al., 1984), so it is not surprising that semidiurnal tidal variability is overwhelmed by other variability within the thermocline and above the depth of the shelf break where other processes contribute to variability; spectra of velocity (not shown) exhibit semidiurnal peaks throughout the upper $500 \mathrm{~m}$. At $300 \mathrm{~m}$, there is a visible change in the slope of the temperature spectrum around $0.04 \mathrm{cph}$, suggesting influence of internal waves and other processes above that frequency. The local inertial frequency at $36^{\circ} \mathrm{N}$ is $0.05 \mathrm{cph}$, so it follows that the full internal wave frequency band influences the glider observations. Spectra computed using observations along the shelf transect (not shown) are suggestive of a similar change in slope around $0.04 \mathrm{cph}$, but the short record length along the shelf transect (typically 2-3 days for pairs of inbound and outbound transects, Figure 2) limits frequency resolution.

Based on the average speed of the gliders over the ground (Figures $2 \mathrm{c}$ and $2 \mathrm{f}$ ), we can estimate the equivalent wavenumber for a given frequency (e.g., Figure 5, upper axis). As noted by Rudnick et al. (2017), variability in glider speed leads to errors in the equivalence between frequency and wavenumber. For the slope transect, the change in spectral slope occurs just above an equivalent wavenumber of 0.04 cycles per kilometer (cpkm). This is a slightly higher wavenumber than has been found for glider observations in the central (Rudnick \& Cole, 2011) and eastern (Rudnick et al., 2017) North Pacific, perhaps due to the relatively weak tidal variability near Cape Hatteras. The slower speed over the ground of gliders along the shelf transect results in a frequency of $0.04 \mathrm{cph}$ corresponding to approximately $0.1 \mathrm{cpkm}$. It follows that the Spray glider observations along the slope transect resolve spatial variability at wavelengths longer than about $25 \mathrm{~km}$ and those along the shelf transect resolve variability at wavelengths longer than about $10 \mathrm{~km}$.

\subsection{Ancillary Observations}

In addition to the Spray glider observations, we make use of selected sea surface temperature (SST) images from the Advanced Very High Resolution Radiometers aboard the NOAA-18 and NOAA-19 weather satellites and winds measured by buoys over the outer continental shelf. The SST images provide spatially broad context to the glider observations; relatively cloud free images are chosen that coincide with events examined in section 3.4.2. Hourly winds from National Data Buoy Center (NDBC) buoys 44066, 44014, and 41025, spanning from near Hudson Canyon $\left(39.6^{\circ} \mathrm{N}\right)$ to Diamond Shoals $\left(35.0^{\circ} \mathrm{N}\right)$ provide an indication of surface forcing over a region larger than directly observed by the gliders. Best track estimates of the eye location for 
Hurricanes Jose (2017), Maria (2017), Chris (2018), and Florence (2018) at six-hourly intervals are obtained from NOAA's Automated Tropical Cyclone Forecast System (ATCFS; Sampson \& Schrader, 2000).

\subsection{Mean and Annual Cycle by Least Squares}

We estimate the time-means and annual cycles of potential temperature, salinity, density, and currents as functions of along-transect position and depth for both the slope and shelf transects. We follow the procedure developed by Rudnick et al. (2017) to estimate the mean and annual cycle from repeat glider transects in the California Current System, which is summarized here. We construct a horizontal grid along each nominal transect with resolution of $5 \mathrm{~km}$ along the slope transect and $1 \mathrm{~km}$ along the shelf transect. The grids span the portion of each nominal transect reached by at least $50 \%$ of individual occupations of the transect (Figures 1c and 1d). A weighted least-squares fit of the mean and first three annual harmonics is performed at each grid point and each depth for each variable, yielding a set of seven coefficients per variable at each point. Three annual harmonics are fit in order to allow an asymmetric annual cycle while avoiding overfitting of the observations. To filter out high-frequency variability in the observations, the Gaussian weight function $w(x)=\exp \left(-x^{2} / L^{2}\right)$ used in the least squares fit has an $e$-folding length scale of $L=11.25 \mathrm{~km}(L=4.5 \mathrm{~km})$ along the slope (shelf) transect that is chosen so that the argument of the Gaussian is -2 at a wavenumber of $k_{0}=0.04 \mathrm{cpkm}\left(k_{0}=0.1 \mathrm{cpkm}\right)$. These choices of length scale are motivated by the spectra discussed above (Figure 5) and serve to average over variability in the internal wave frequency band, but it is worth noting that the anisotropic length scales resolved by the gliders are broadly consistent with estimates of characteristic length scales of the circulation near the continental shelf break (Gawarkiewicz et al., 2004; He et al., 2010; Todd et al., 2013). The mean and annual cycle are fit to glider observations from the reference period 1 May 2017 to 30 April 2019 (Figures 1c and 1d, gray shading). The resulting annual cycles explain the largest fraction of observed variance $(>70 \%)$ near the surface and for temperature and density, which are most affected by the annual cycle of surface heat flux. Deeper than $150 \mathrm{~m}$, the annual cycles typically explain less than $25 \%$ of observed variance, so we limit our discussion of annual cycles below to the upper portion of the water column.

\subsection{Anomaly Maps}

To produce a low-pass filtered, spatially and temporally gridded product from the repeat glider transects, we again follow Rudnick et al. (2017) and objectively map anomalies from the two-year mean and seasonal cycle. The objective map requires specification of the covariance function. We compute an empirical autocorrelation of potential temperature anomalies from the mean and seasonal cycle at $100 \mathrm{~m}$ as a function of both spatial and temporal lags in bins of 10 days and $10 \mathrm{~km}$ along the slope transect. The temporal bin size is chosen to span between successive transects (Figure $2 \mathrm{~g}$ ).

The resulting autocorrelation (Figure 6b) is sharply peaked in the center, indicating a high degree of variability at small spatial and temporal scales that is incoherent between repeat transects, even with transects repeated about every 8 days. For the purposes of forming a low-pass-filtered product, this small-scale variability is treated as "noise." Despite the small scale variability, there remains a notable correlation in both time and space at larger scales. Since distance increases southward along the slope transect, the slight tilt of the autocorrelation function is consistent with a tendency toward southward propagation of anomalies, as may be expected in the presence of generally southward flow along the MAB shelf and slope.

We seek an appropriate functional form for the autocorrelation to use in the objective mapping. Least-squares fitting of a Gaussian function with added noise to the empirical autocorrelation yields temporal and spatial scales of 28 days and $118 \mathrm{~km}$, respectively. The length scale is long because the anomalies from the mean and seasonal cycle include interannual variability at large spatial scales. To avoid such strong smoothing, we choose to specify a Gaussian autocovariance function with a time scale of 25 days and a length scale of $30 \mathrm{~km}$ to map anomalies along the slope transect; uncorrelated noise with a noise-to-signal ratio of 2 is added at zero lag to account for small-scale variability in the observations that is not to be resolved by the objective map. The specified Gaussian covariance function with added noise agrees well with the empirical autocorrelation at zero spatial lag (Figure 6a) while decaying more rapidly as a function of spatial lag due to the shorter spatial scale chosen (Figure 6c). For the shelf transect, we choose a Gaussian length scale of $10 \mathrm{~km}$ for the autocorrelation. For both transects, the scale inherent to the mapping is somewhat longer than the scale used to fit the mean and annual cycle since the anomaly maps do not benefit from averaging across years (see Rudnick et al., 2017). 


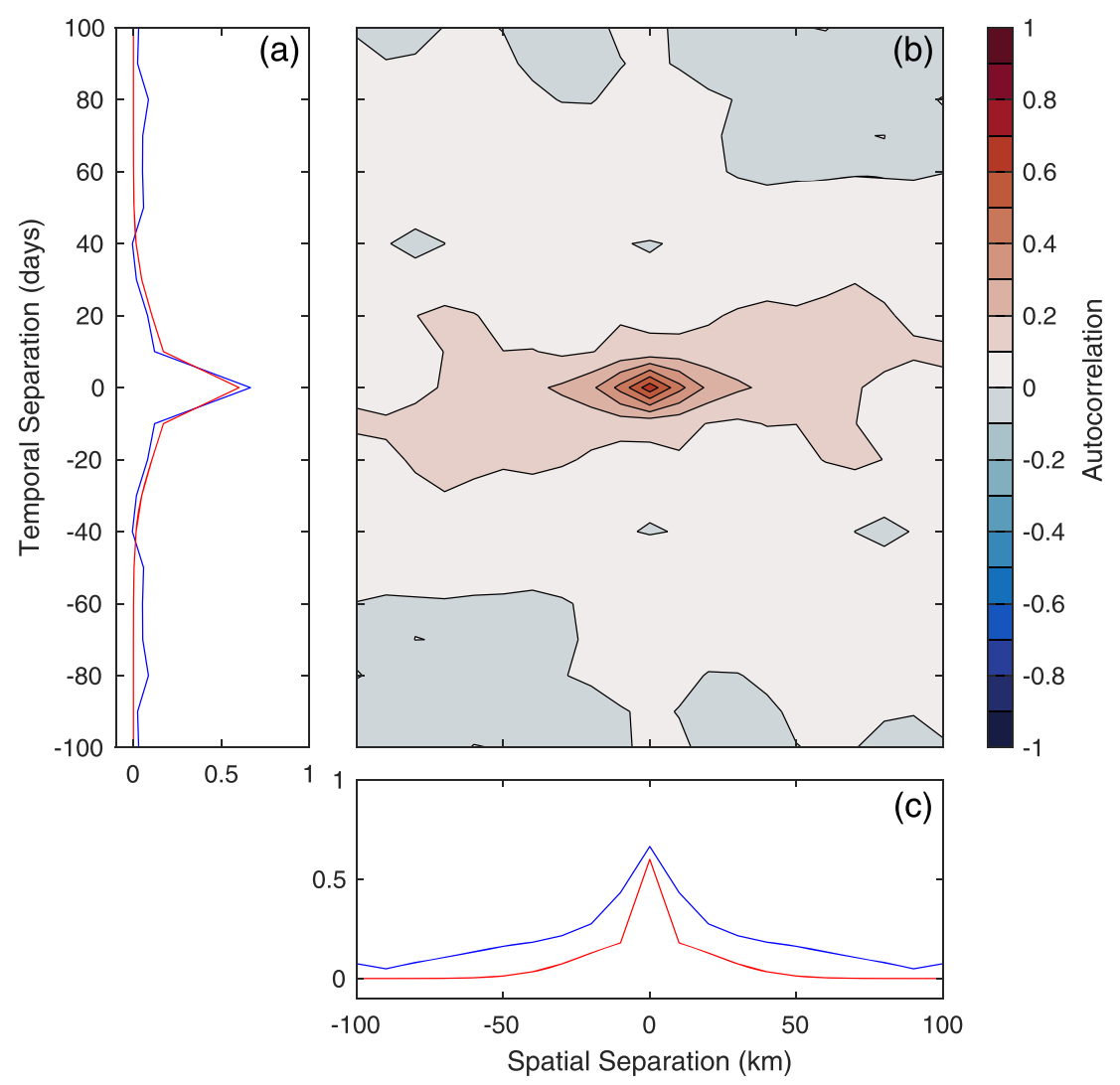

Figure 6. Autocorrelation of potential temperature in the upper $100 \mathrm{~m}$ along the slope transect. Side (bottom) panel shows the empirical autocorrelation at zero spatial (temporal) lag in blue and the Gaussian with added noise used for objective mapping in red.

Objective maps of potential temperature, salinity, potential density, along-shore velocity, and cross-shore velocity anomalies are produced at each depth level along both the slope and shelf transect. The appropriate mean and seasonal cycle are then added back to the mapped anomalies to produce low-pass-filtered and uniformly gridded products. Means and annual cycles are linearly interpolated (or extrapolated near edges of the sampling domain) to observation and grid locations. The objective mapping formalism provides an estimate of the error in the map; we mask the maps shown here when the error-to-signal variance ratio exceeds 0.3 . The result of the mapping is fields of variables on a regular grid of $10 \mathrm{~m}$ in the vertical by $1 \mathrm{~km}$ in the horizontal by 1 day along both the slope and shelf transects. From this low-pass-filtered product, various analyses can be conducted.

\section{Results and Discussion}

Here we first examine the means and annual cycles obtained by weighted least-squares fits to the glider observations during the two years from May 2017 through April 2019 along both the slope and shelf transects (sections 3.1 and 3.2). We then show examples of the gridded and low-pass-filtered fields for each transect (section 3.3) before combining the gridded products and direct observations to show that export of MAB shelf waters near Cape Hatteras primarily occurs during discrete export events (section 3.4.1). A selection of these events is then examined individually (section 3.4.2).

\subsection{Mean}

Sustained glider observations during PEACH allow us to produce a unique, spatially resolved, multi-year mean picture of the circulation at the southern end of the MAB (Figure 7). With observations from only two full years included, these averages should not be taken to represent the climatological circulation, yet a number of the expected features are evident in the mean.

The mean along the slope transect (Figure 7, left) captures along-shore convergence and net export from the shelf. At the southern end of the transect, strong northeastward flow of warm, salty waters is indicative 

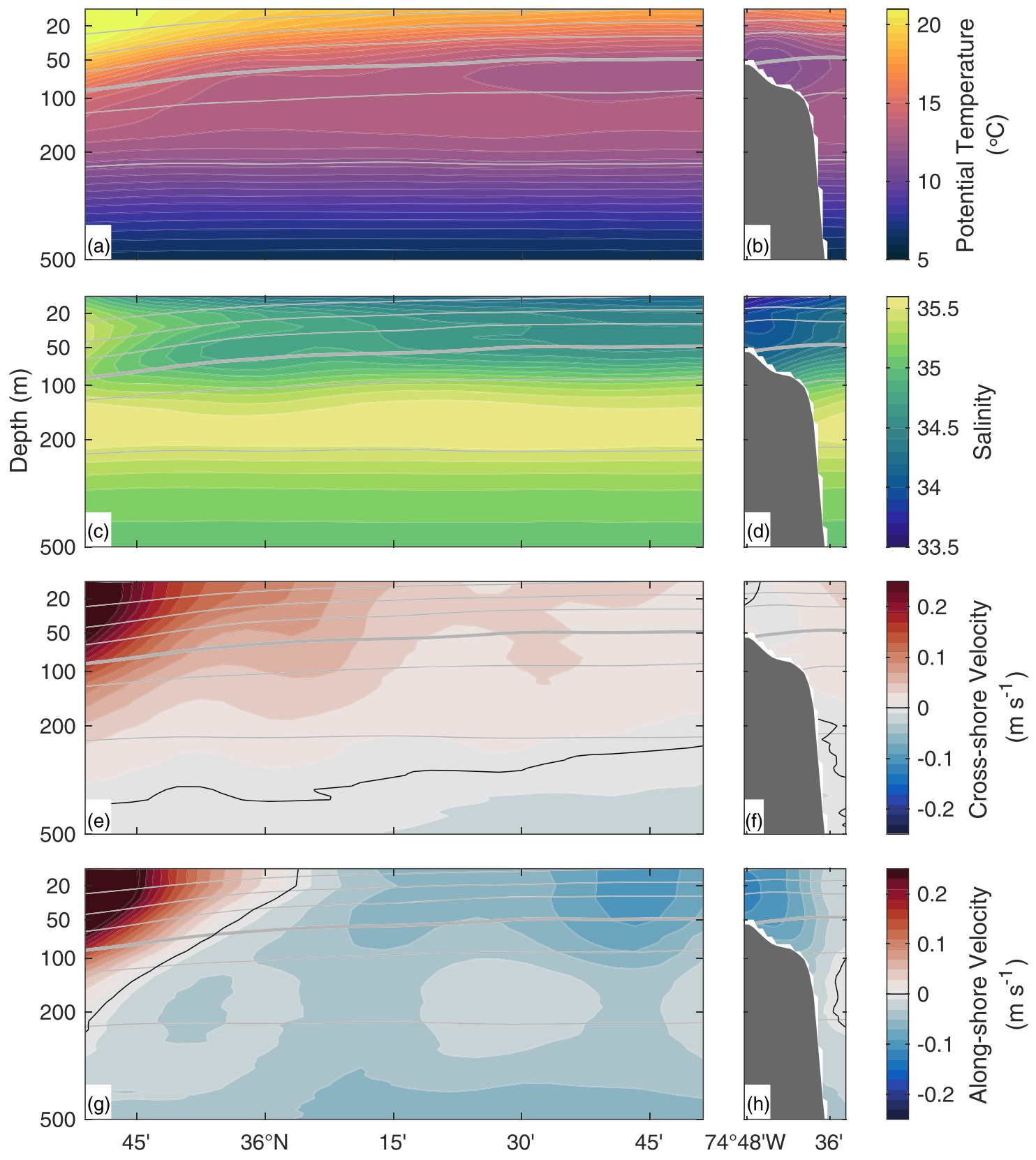

Figure 7. Mean fields along the slope transect (left) and shelf transect (right). (a-b) Potential temperature, (c-d) salinity, (e-f) cross-shore velocity, and (g-h) along-shore velocity. Gray contours are isopycnals with a contour interval of $0.5 \mathrm{~kg} \mathrm{~m}^{-3}$ and the $26 \mathrm{~kg} \mathrm{~m}^{-3}$ isopycnal bold. The zero contours of the velocity components are black in $(\mathrm{e}-\mathrm{h})$.

of the Gulf Stream's presence as it separates from the continental margin at Cape Hatteras. North of about $36^{\circ} \mathrm{N}$, cooler, fresher waters of MAB origin occupy the upper $100 \mathrm{~m}$. Below about $150 \mathrm{~m}$ (i.e., approximately the depth of the continental shelf), time-mean water mass properties are nearly horizontally uniform along the slope transect (Figures 7a and 7c). Mean along-shore flow (Figure 7g) is southward from the northern end of the slope transect to approximately $36^{\circ} \mathrm{N}$. This latitude may be interpreted as the average endpoint for the southward flow of the MAB shelfbreak jet along the upper continental slope. Near $500 \mathrm{~m}$, mean southward flow and water properties are consistent with the uppermost portion of the DWBC, which carries upper Labrador Sea Water southward (e.g., Andres et al., 2018). Time-mean cross-shore flow (Figure 7e) is directed offshore everywhere above $200 \mathrm{~m}$, consistent with net convergence over the continental shelf driving export from the shelf in the vicinity of Cape Hatteras. Though not the focus here, we note the presence of weak onshore flow at depth (Figure 7e). 

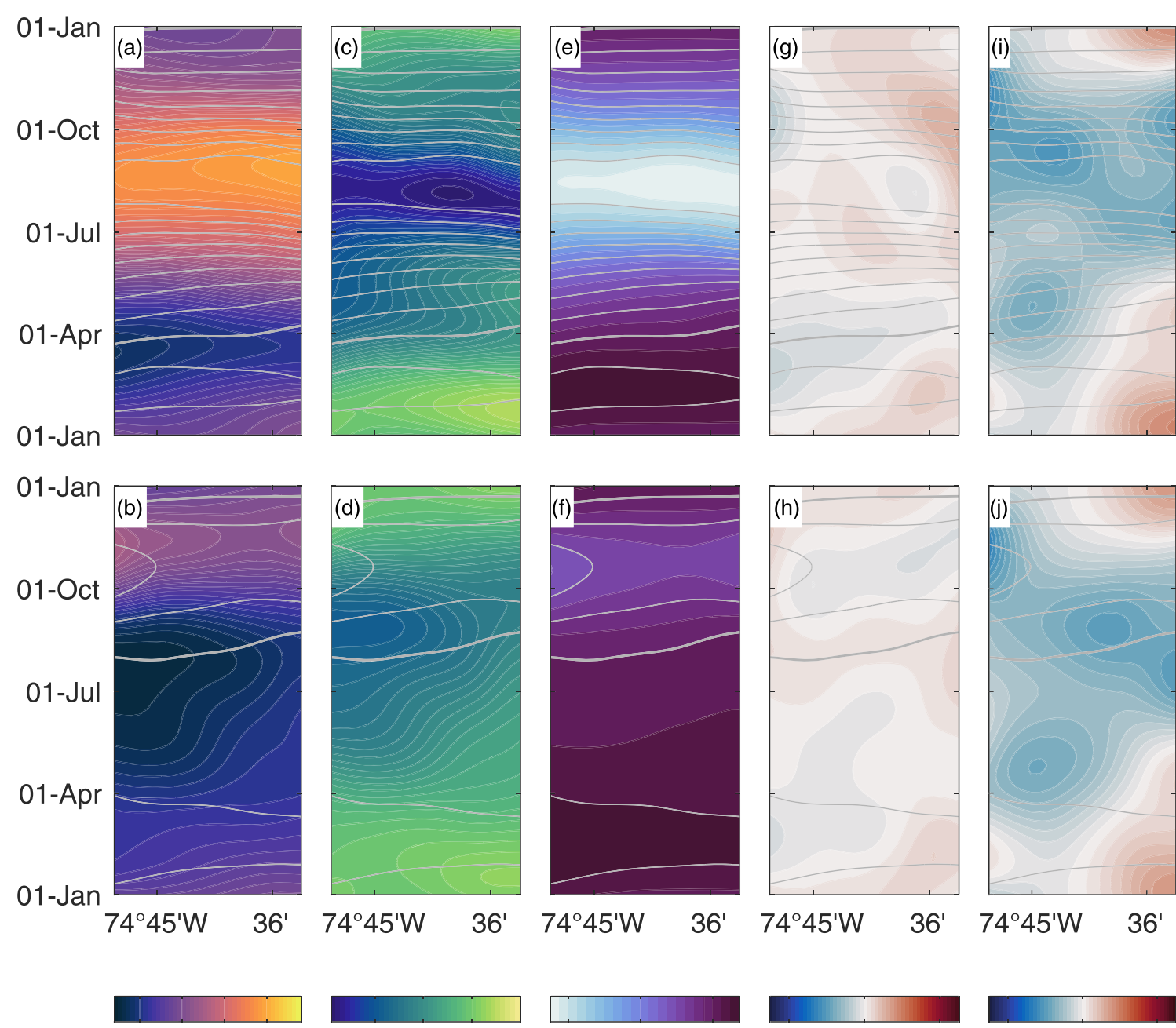

$\begin{array}{llll}10 & 15 & 20 & 25\end{array}$

Potential Temperature

$\left({ }^{\circ} \mathrm{C}\right)$
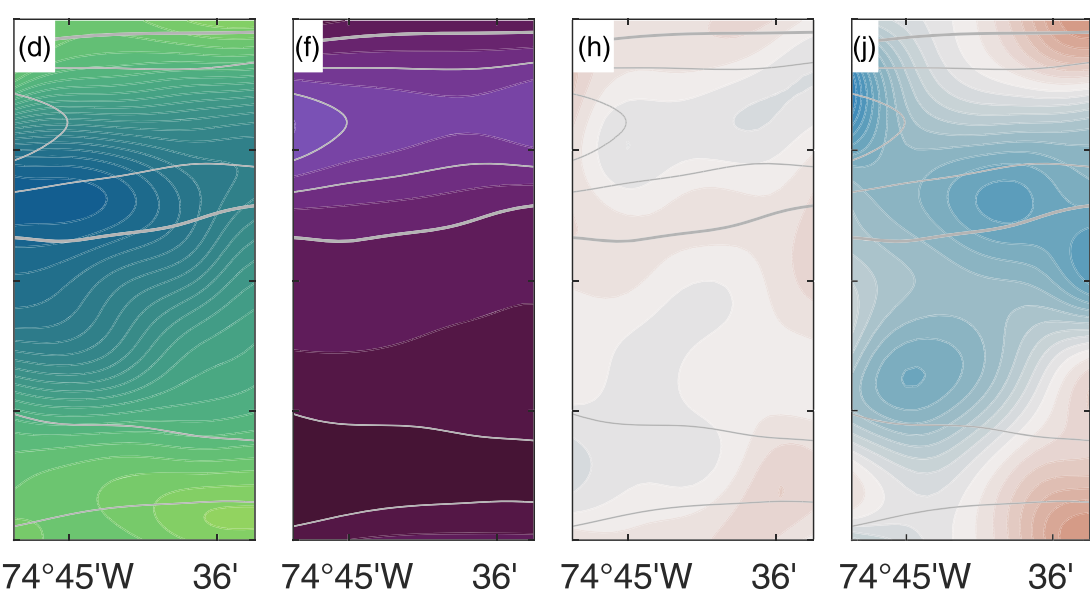

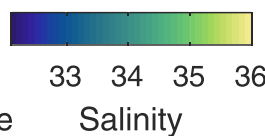

Salinity

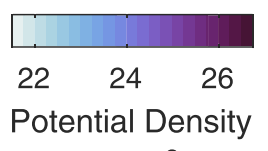

$\left(\mathrm{kg} \mathrm{m}^{-3}\right)$

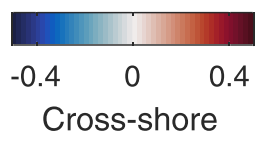

Velocity $\left(\mathrm{m} \mathrm{s}^{-1}\right)$

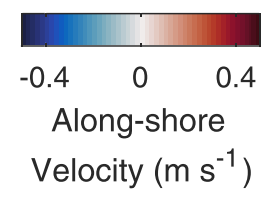

Figure 8. Annual cycles of (a-b) potential temperature, (c-d) salinity, (e-f) potential density, ( $\mathrm{g}-\mathrm{h})$ cross-shore velocity, and (i-j) along-shore velocity at depths of (top) $10 \mathrm{~m}$ and (bottom) $50 \mathrm{~m}$ along the shelf transect. Gray contours are isopycnals with a contour interval of $0.5 \mathrm{~kg} \mathrm{~m}^{-3} \mathrm{and} \mathrm{the} 26 \mathrm{~kg} \mathrm{~m}^{-3}$ isopycnal bold. Color limits are as in Figure 9.

Along the shelf transect near $37^{\circ} \mathrm{N}$ (Figure 7, right), the standout features in the time mean are the MAB shelfbreak front and associated southward shelfbreak jet (Figure 7h), both of which are most prominent shoreward of the shelf break (approximately the 150-m isobath). The shelfbreak front separates cool, fresh shelf waters from warmer, saltier waters over the continental slope (Figures $7 \mathrm{~b}$ and $7 \mathrm{~d}$ ), yet density gradients across the front are weak with isopycnals in the upper $50 \mathrm{~m}$ nearly flat and a seaward increase in density at a depth of $50 \mathrm{~m}$. Consistent with this, the mean shelfbreak jet is weakly sheared (Figure 7h). The nearly complete compensation of cross-frontal temperature and salinity gradients in the time mean near $37^{\circ} \mathrm{N}$ contrasts with observations (e.g., Gawarkiewicz et al., 2018; Linder \& Gawarkiewicz, 1998) and numerical simulations (e.g., Zhang et al., 2011) of the shelfbreak front in the central and northern MAB (and for different time periods) that show an offshore increase in density. Seaward of the shelfbreak below $200 \mathrm{~m}$, water properties match those along the slope transect at the same depths. The uppermost DWBC is apparent in the deepest part of the shelf transect, indicating that the DWBC closely follows the upper continental slope to this latitude. 


\subsection{Annual Cycles}

We next highlight key features in the annual cycles obtained from least-squares fits to the glider observations. It is important to note that these are annual cycles are derived from only two years of observations. Nevertheless, several key features are worth noting.

\subsubsection{Shelf Transect}

Temperature along the shelf transect exhibits an annual cycle (Figures $8 \mathrm{a}$ and $8 \mathrm{~b}$ ) that generally agrees with prior studies of seasonality in the Hatteras region and the MAB more broadly. Near the surface, temperatures are coldest at all cross-shelf positions in late winter with the lowest temperatures below $9{ }^{\circ} \mathrm{C}$ inshore in mid-March. Near-surface waters are warmest in late summer with the highest temperatures exceeding $24^{\circ} \mathrm{C}$ offshore in late August (Figure 8a). At a depth of $50 \mathrm{~m}$, near the seafloor over the continental shelf, the phasing of the annual cycle of temperature is markedly different. Coldest temperatures of about $7.5^{\circ} \mathrm{C}$ are found in late July over the shelf and warmest temperatures of over $17^{\circ} \mathrm{C}$ occur in mid-November (Figure 8b). The delayed appearance of coldest waters near the seafloor results from southward advection of MAB Cold Pool waters that are formed in late winter over the MAB shelf south of New England (see Houghton et al., 1982). At a typical speed of $0.05 \mathrm{~m} \mathrm{~s}^{-1}$ (Houghton et al., 1982), Cold Pool waters formed $500 \mathrm{~km}$ from our shelf transect would reach the shelf transect in about 115 days. Coldest subsurface waters observed around year day 206 at the shelf transect (Figure 8b) are consistent with temperature being set in late March or early April over the northern MAB shelf (e.g., Lentz, 2017). Warmest near-bottom waters over the shelf occur in fall, presumably as warmer surface waters are mixed downward by storms (e.g., Chen et al., 2018; Fleming, 2016).

Salinity along the shelf transect also exhibits an annual cycle (Figures 8c and 8d). Near-surface waters are generally saltiest in mid-winter with the highest salinity $(>35.4)$ at the offshore end of the transect. Freshest near-surface waters transect-wide occur in mid-summer with minimum salinity $(<32.2)$ near the 100 -m isobath (approximately $74^{\circ} 39^{\prime} \mathrm{W}$ ). This summertime salinity minimum may be attributable to arrival of the spring freshet in the region; Castelao et al. (2008) provide evidence of cross-shelf transport of fresh waters from the Hudson River during the same time of year, suggesting a mechanism by which very fresh waters could reach the shelf break and then the area sampled by PEACH gliders. At $50 \mathrm{~m}$, waters are saltiest in winter and freshest in summer (Figure 8d). The minimum salinity of about 33.1 at the inshore end of the transect occurs in late August, about 1 month after the coldest temperatures are observed (Figure 8b). The arrival of the freshest near-bottom waters is likely attributable to advection of Cold Pool waters with the delay relative to minimum temperatures resulting from Cold Pool waters warming as they are advected southward.

Near-surface density along the shelf transect varies by about $5 \mathrm{~kg} \mathrm{~m}^{-3}$ from its lightest in late summer to its densest in winter (Figure 8e); the nearly in phase temperature maximum and salinity minimum at $10 \mathrm{~m}$ (Figures $8 \mathrm{a}$ and $8 \mathrm{c}$ ) lead to the summer density minimum. With a magnitude of about $1.8 \mathrm{~kg} \mathrm{~m}^{-3}$, the annual cycle in density at $50 \mathrm{~m}$ (Figure $8 \mathrm{f}$ ) is about a third as large as at $10 \mathrm{~m}$. For these annual cycles, cross-shelf density differences across the shelf break are typically less than $0.25 \mathrm{~kg} \mathrm{~m}^{-3}$. For comparison, Gawarkiewicz et al. (2008) report density differences across the shelfbreak front in winter 2005 ranging from 0.179 to 0.271 $\mathrm{kg} \mathrm{m}^{-3}$.

Along-shore velocity through the shelf transect showed a prominent annual cycle with peak southward flow in summer (Figures $8 \mathrm{i}$ and 8j). This annual cycle is largely the same at depths of 10 and $50 \mathrm{~m}$, suggesting that, like the mean along-shore flow (Figure $7 \mathrm{~h}$ ), the annual cycle of along-shelf flow is largely barotropic. The annual cycle of cross-shore velocity was weak with maximum speeds typically less than $0.05 \mathrm{~m} \mathrm{~s}^{-1}$ (Figures $8 \mathrm{~g}$ and $8 \mathrm{~h}$ ).

\subsubsection{Slope Transect}

Along the slope transect, the annual cycle of temperature (Figures 9a and 9b) is qualitatively similar to that along the shelf transect (Figures $8 \mathrm{a}$ and $8 \mathrm{~b}$ ) with warmest temperatures in mid-to-late summer and coolest temperatures in late winter; the temporal cycle is superimposed on the along-shelf temperature gradient of the time mean (Figure 7a) with no notable phase shift along the transect. At $50 \mathrm{~m}$, the annual cycle shows minimum temperatures of $10^{\circ} \mathrm{C}$ in mid-to-late July (Figure 9b), approximately in phase with coldest near-bottom temperatures along the shelf transect (Figure 8b); these Cold Pool waters are evident along the slope transect as far south as $36^{\circ} \mathrm{N}$. As for the shelf transect, warmest waters at $50 \mathrm{~m}$ along the slope transect are found in fall.

The annual cycle of salinity along the slope transect (Figures $9 c$ and $9 d$ ) is much like the annual cycle of salinity along the shelf transect (Figures $8 \mathrm{c}$ and $8 \mathrm{~d}$ ) with a pulse of low salinity $(<32.4)$ water near the surface 

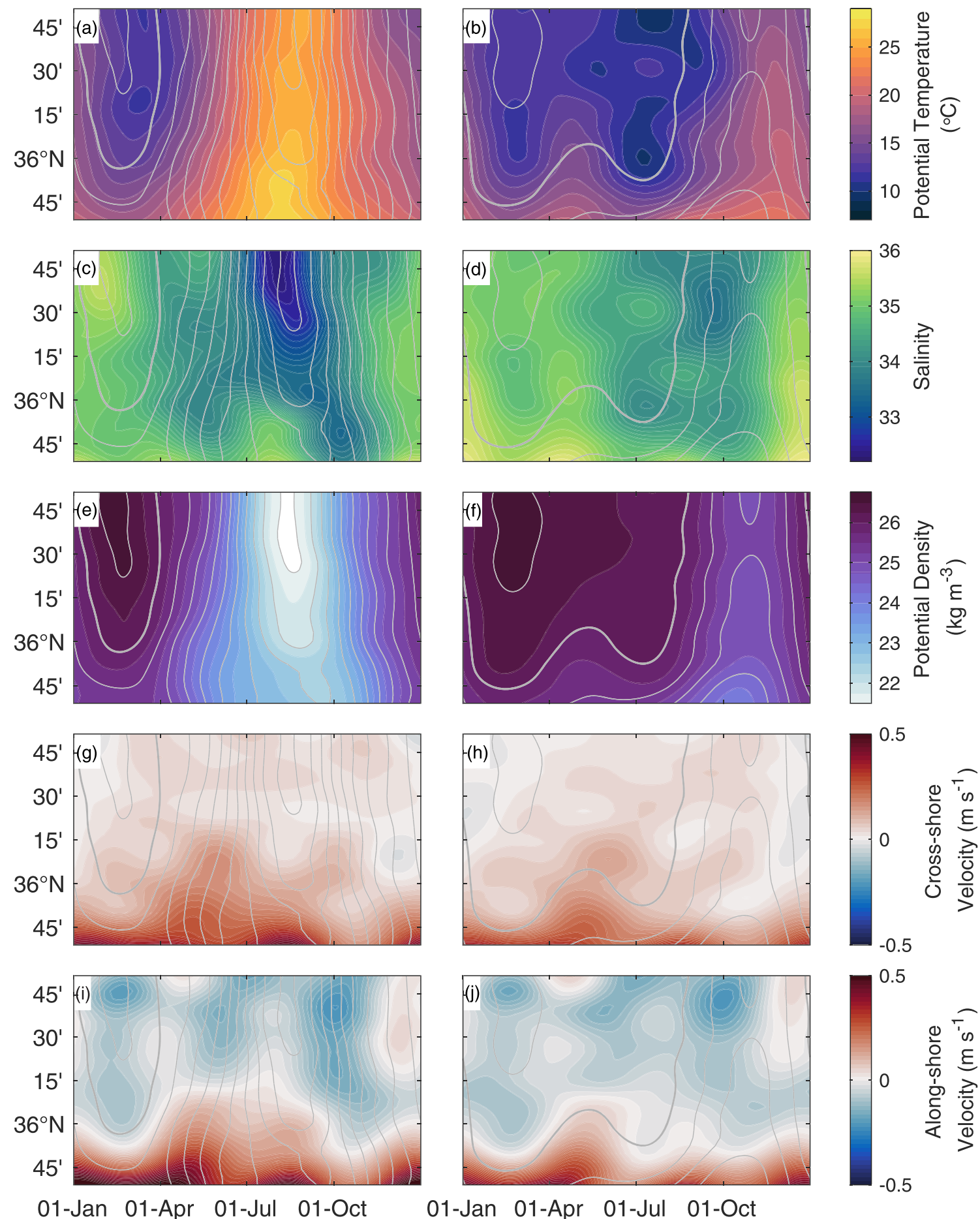

Figure 9. Annual cycles of (a-b) potential temperature, (c-d) salinity, (e-f) potential density, ( $\mathrm{g}-\mathrm{h}$ ) cross-shore velocity, and (i-j) along-shore velocity at depths of (left) $10 \mathrm{~m}$ and (right) $50 \mathrm{~m}$ along the slope transect. Gray contours are isopycnals with a contour interval of $0.5 \mathrm{~kg} \mathrm{~m}^{-3}$ and the $26 \mathrm{~kg} \mathrm{~m}^{-3}$ isopycnal bold. Color limits are as in Figure 8. 

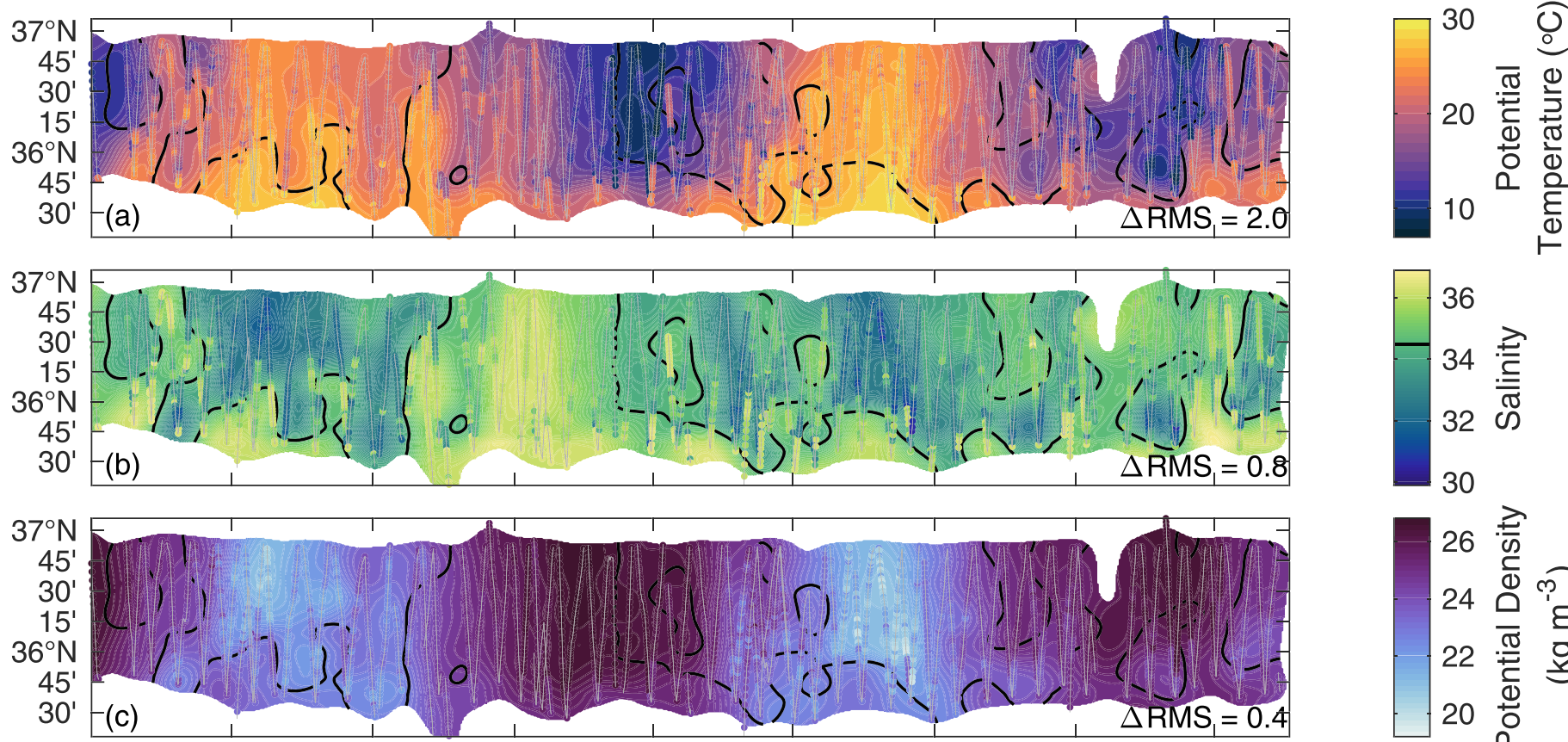

30

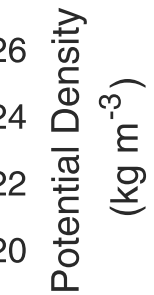
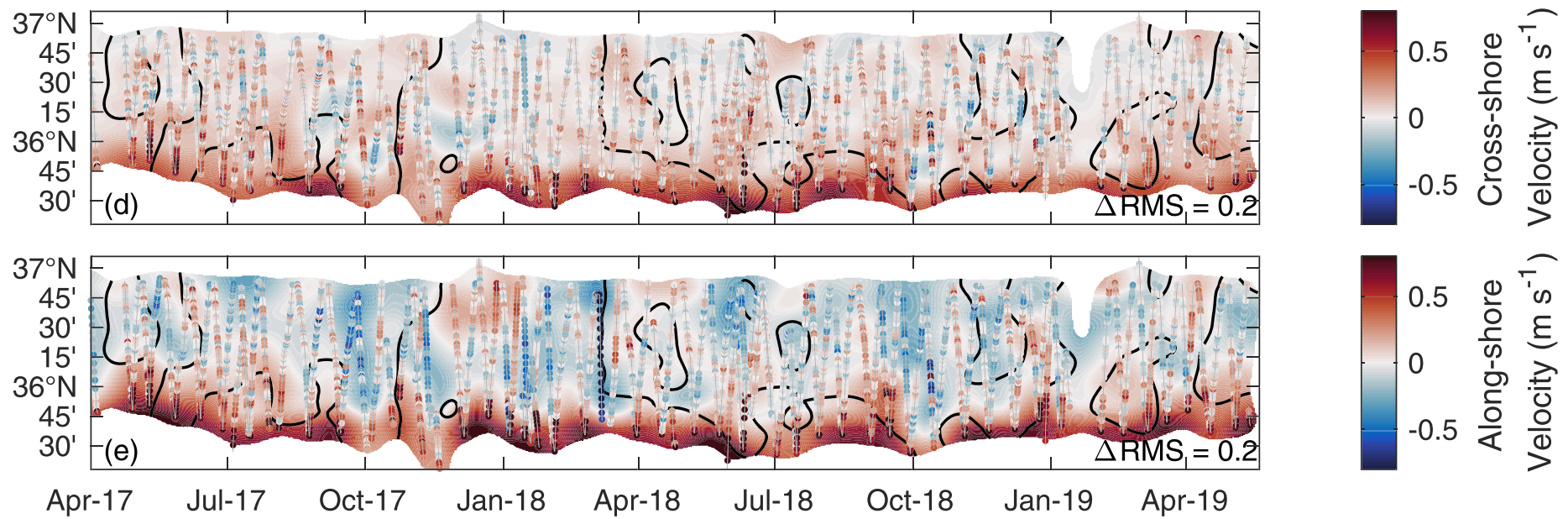

Figure 10. Low-pass-filtered, gridded fields of (a) potential temperature, (b) salinity, (c) potential density, (d) cross-shore velocity, and (e) along-shore velocity at a depth of $10 \mathrm{~m}$ along the slope transect are shown as contoured fields. The 34.5 isohaline is drawn in black in all panels. Gray lines show the trajectories of gliders as functions of latitude and time along the slope transect. Colored dots represent the underlying observations that were mapped; where dots are not visible along the gray trajectories, the gridded fields match the observations particularly closely. Root-mean-square differences between the original observations and the gridded product are given in the lower right of each panel.

in summer (Figure 9c) and a summer salinity minimum at $50 \mathrm{~m}$ (minimum of about 33.6 at $36^{\circ} 36^{\prime} \mathrm{N}$ in mid-September; Figure 9d).

The magnitude of the annual cycle of density at $10 \mathrm{~m}$ along the slope transect decreases from about $5 \mathrm{~kg} \mathrm{~m}^{-3}$ at the northern end of the transect to about $3 \mathrm{~kg} \mathrm{~m}^{-3}$ at the southern end of the transect in the vicinity of the Gulf Stream (Figure 9e). The larger annual cycle at the northern end of the transect leads to a reversal of the along-shelf density gradient from winter to summer. At $50 \mathrm{~m}$, the annual cycle of density (Figure 9f) largely parallels that of temperature (Figure 9b) with minimum densities in summer occurring slightly earlier than maximum temperatures due to the timing of the salinity minimum at $50 \mathrm{~m}$ (Figure $9 \mathrm{~d}$ ).

An annual cycle is apparent in both cross-shore and along-shore velocity along the slope transect (Figures 9g-9j). Between about $36^{\circ} 15^{\prime} \mathrm{N}$ and the northern edge of the Gulf Stream near $35^{\circ} 45^{\prime} \mathrm{N}$, cross-shore velocity becomes more strongly offshore from late winter through summer (Figures $9 \mathrm{~g}$ and $9 \mathrm{~h}$ ). During the 

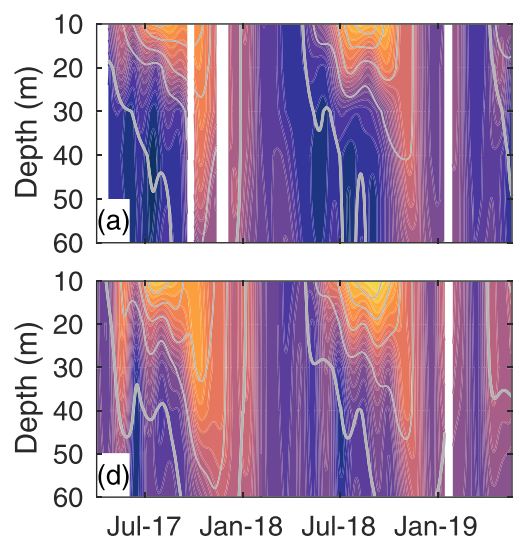

Jul-17 Jan-18 Jul-18 Jan-19

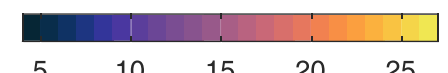

Potential Temperature $\left({ }^{\circ} \mathrm{C}\right)$

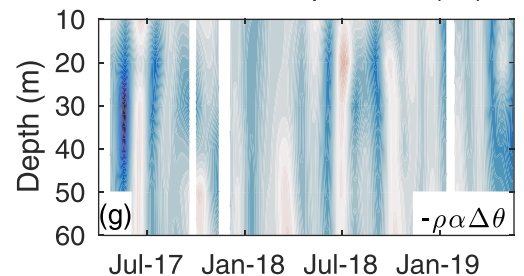

Jul-17 Jan-18 Jul-18 Jan-19
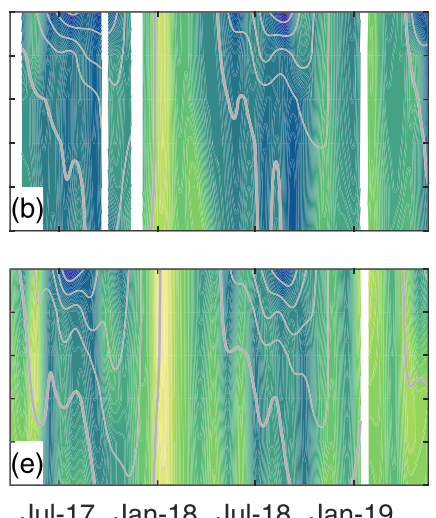

Jul-17 Jan-18 Jul-18 Jan-19
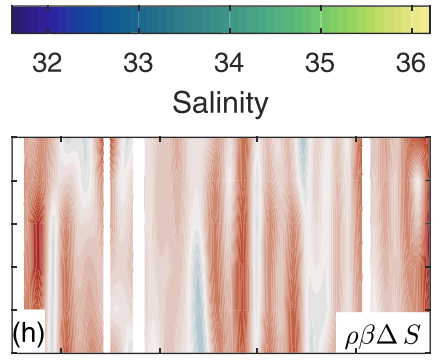

Jul-17 Jan-18 Jul-18 Jan-19
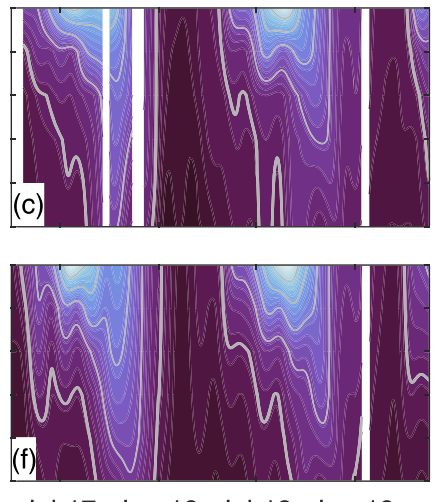

Jul-17 Jan-18 Jul-18 Jan-19

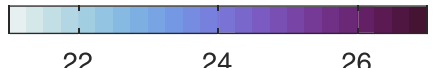

In Situ Density $\left(\mathrm{kg} \mathrm{m}^{-3}\right)$

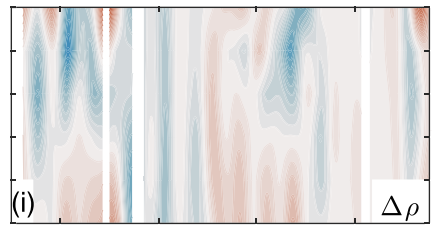

Jul-17 Jan-18 Jul-18 Jan-19

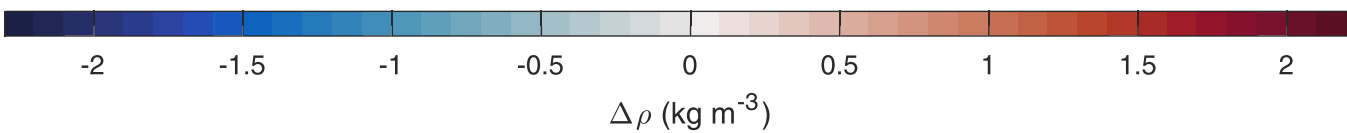

Figure 11. (a-f) Time series of (left) potential temperature, (center) salinity, and (right) in situ density $\rho$ at (a-c) $36^{\circ} 54^{\prime} \mathrm{N}, 74^{\circ} 45^{\prime} \mathrm{W}$ along the shelf transect and $(\mathrm{d}-\mathrm{f})$ at $36^{\circ} 45^{\prime} \mathrm{N}, 74^{\circ} 34^{\prime} \mathrm{W}$ along the slope transect from the gridded products. Gray contours are isopycnals with a contour interval of $1 \mathrm{~kg} \mathrm{~m}^{-3}$ and the $26 \mathrm{~kg}$ $\mathrm{m}^{-3}$ isopycnal bold. (g-i) Time series of differences between the slope and shelf of (g) potential temperature, (h) salinity, and (i) in situ density with potential temperature and salinity difference scaled to reflect their influence on in situ density differences.

same portion of the year, the latitude at which the along-shore velocity changes sign shifts northward from about $35^{\circ} 45^{\prime} \mathrm{N}$ to about $36^{\circ} 15^{\prime} \mathrm{N}$ (Figures $9 \mathrm{i}$ and $9 \mathrm{j}$ ). Taken together with the amplification of along-shore flow at the shelf transect during summer and fall (Figures $8 \mathrm{i}$ and $8 \mathrm{j}$ ), a picture emerges of a spring-summer tendency toward increased along-shore flow into the Hatteras region that feeds increased offshore transport.

\subsection{Low-Pass-Filtered, Gridded Product}

The fundamental output resulting from the mapping procedure described in section 2.4 is a set of fields gridded in time and along-transect distance at each depth. As an example, consider the properties at a depth of $10 \mathrm{~m}$ along the slope transect (Figure 10). The mapping allows us to fill in the spatial and temporal gaps between the irregularly spaced observations (colored dots in Figure 10) while applying a low-pass filter in space and time. Differences between the mapped fields and the observations, as represented by the root-mean-square difference ( $\triangle \mathrm{RMS}$ in Figure 10 ), are typically about $10 \%$ of the range of values for a particular variable. These mismatches largely result from the low-pass-filtered product not capturing observed variability at spatial and temporal scales smaller than the $30-\mathrm{km}$ and 25 -day scales built into the covariance function (Figure 6) used to produce the maps. The error field associated with the objective maps allows masking of the gridded product where observations are sparse; the variable extent of successive transects leads to irregular borders of the mapped product.

The gridded products for the slope and shelf transects are three-dimensional (along-transect, depth, and time), and so can be displayed in a variety of ways. For instance, although the gliders did not collect time series at fixed locations along the transects, we can extract low-pass-filtered time series at specific locations from the gridded products. Figures 11a-11f present time series extracted from the gridded products 

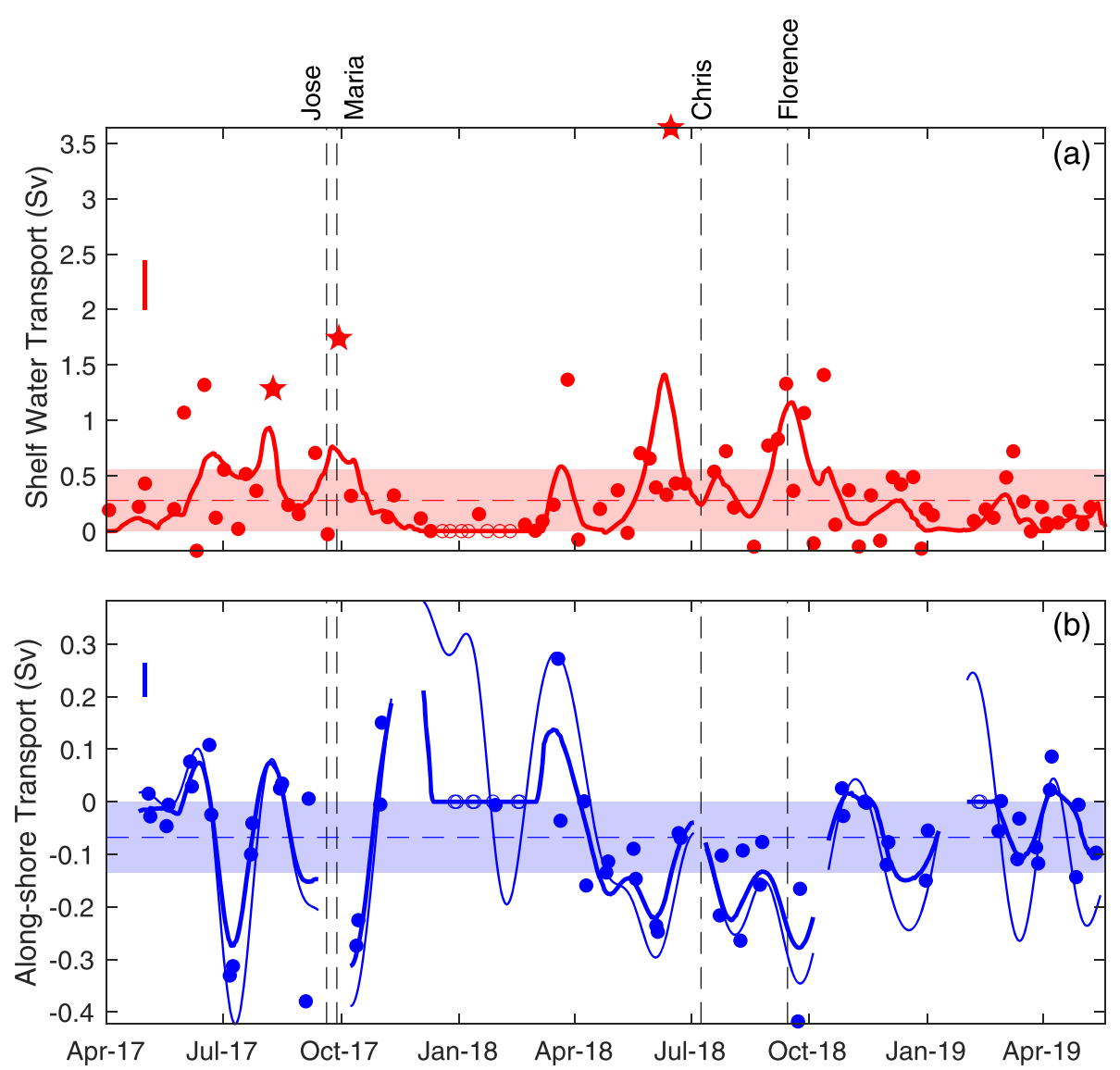

Figure 12. (a) Time series of transport of MAB shelf waters with salinity less than 34.5 through the slope transect. Circles are from individual glider transects with open circles at zero transport when no waters with salinities less than 34.5 were observed along a transect. Stars indicate transects shown in Figures 3, 14, and 15. The solid line is from the gridded, low-pass-filtered product with the mean and standard deviation indicated by the dashed line and shading, respectively. The vertical bar indicates the root-mean-square mismatch between the values from individual transects and the gridded product at the same times. (b) As in (a) for transport through the shelf transect with the addition of a thin line representing transport of waters of all salinities through the transect. Dashed vertical lines in each panel denote the times of closest approach for hurricanes in 2017 and 2018 based on ATCFS data.

at $36^{\circ} 54^{\prime} \mathrm{N}, 74^{\circ} 45^{\prime} \mathrm{W}$ along the shelf transect and at $36^{\circ} 45^{\prime} \mathrm{N}, 74^{\circ} 34^{\prime} \mathrm{W}$ along the slope transect, respectively; these locations were chosen to maximize cross-shelf separation at similar along-shelf positions while being well sampled. Gaps in the time series result at times when spacing between glider occupations of the transects were long compared to the 25-day time scale of the mapping routine. Movie S1 supporting information showing the time-evolving hydrography and circulation along the slope and shelf transects is available in the online supporting information.

\subsection{Export of MAB Shelf Waters Near Cape Hatteras}

We now focus on the variability in export of MAB shelf waters during the PEACH observation period. We will define MAB shelf waters as all waters having salinities less than 34.5. This choice of isohaline is consistent with various prior studies; for instance, Linder and Gawarkiewicz (1998) show that it characterizes the center of the MAB shelfbreak front. In section 3.4.1, we first consider the temporal evolution of MAB shelf water export during the full analysis period, showing that the export is largely event-driven. We then focus on several outstanding events during the period in section 3.4.2.

\subsubsection{Temporal Variability}

We quantify the export of MAB shelf waters across the slope transect using both the individual transects and the gridded product (Figure 12a). Transport of shelf waters across an individual glider transect or at a particular time in the gridded product is defined as 


$$
T_{\mathrm{MAB}}=\sum_{i} \sum_{j} v_{\perp, i j} H\left(S_{0}-S_{i j}\right) \Delta x_{j} \Delta z_{i}
$$

where $v_{\perp, i j}$ is the flow locally perpendicular to the transect (positive offshore), $H$ is the Heaviside function, $S_{0}=34.5, S_{i j}$ is local salinity, $\Delta x_{j}$ is the distance covered during each glider dive or the 1-km grid spacing, and $\Delta z_{i}=10 \mathrm{~m}$ is the vertical bin size. Estimates of transport from both the individual transects and the gridded product are influenced by variable horizontal integration limits resulting from the glider sampling being determined by both Gulf Stream position and operational constraints (Figure 1c). Only transports through individual glider transects that covered at least the latitudes $35^{\circ} 50^{\prime} \mathrm{N}$ to $36^{\circ} 41^{\prime} \mathrm{N}$ are used. Transports estimated from the gridded product use only portions of the transect for which the ratio of mapping error to signal is less than 0.3 (see variable edges in Figure 10). Transports through individual glider transects (Figure 12a, discrete symbols) are akin to averages over the time required to occupy each transect and are somewhat irregularly spaced in time. The gridded product allows for estimation of a time series of MAB shelf water transport through the slope transect (Figure 12a, solid line), from which we compute a mean and standard deviation. MAB shelf water export estimated from the gridded product misses the extremes in export due to the low-pass filtering but generally agrees well with transport estimated from individual glider transects (RMS difference $<0.5$ Sv, Figure 12a).

During the April 2017-May 2019 period, the transport of MAB waters across the slope transect averaged $0.3 \mathrm{~Sv}$; the standard deviation of MAB shelf water transport was also $0.3 \mathrm{~Sv}$ (Figure 12a, horizontal dashed line and shading). Given the large variability relative to the mean and an integral time scale not shorter than the 25-day scale built into the objective mapping, which yields not more than 30 degrees of freedom, we report the mean and standard deviation with only a single significant digit. For comparison, Savidge and Bane (2001) inferred cross-shore transport of all water types of $0.24 \pm 0.19 \mathrm{~Sv}$ (mean \pm standard deviation) over a narrower latitude range from measurements of alongshelf convergence, while typical shelfbreak jet transports are 0.2-0.3 Sv (Linder \& Gawarkiewicz, 1998) and equatorward transport over the shelf and inshore of the shelfbreak jet is typically $~ 0.1 \mathrm{~Sv}$ in the southern MAB (Lentz, 2008; Savidge \& Bane, 2001). Mean export of MAB shelf waters through the PEACH slope transect accounts for most, though not all, of the equatorward transport into the region as estimated previously. In addition to temporal mismatches between estimates, the lower export through the PEACH slope transects is indicative of additional export across the shelf break farther north (e.g., Cenedese et al., 2013; Chen et al., 2014; Churchill \& Cornillon, 1991; Gawarkiewicz \& Linder, 2006; Todd et al., 2013).

Export of MAB shelf waters near Cape Hatteras is dominated by large export events (Figure 12a) rather than quasi-steady export. Based on the time series of MAB shelf water export from the gridded product (Figure 12a, solid line), nearly $50 \%$ of MAB shelf water export in the region occurred during the $17 \%$ of the time when the shelf water transport exceeded the mean by at least one standard deviation (i.e., transport greater than $0.6 \mathrm{~Sv}$ ). Large export of MAB shelf water across the slope transect occurred primarily during the late spring and summer of both 2017 and 2018, consistent with the annual cycles of along- and cross-shore flow discussed above. This result contrasts with the climatological model results of Fleming (2016) that suggest greatest export in December as well as the results from moored observations by Savidge and Bane (2001) that find a semiannual periodicity to export inferred from along-shelf convergence. Whether these differences are due to differing time periods of analysis or differing methods is unclear. Cross-shore transport of MAB waters during individual events exceeded $1 \mathrm{~Sv}$ on several occasions (Figure 12a, symbols), including two export events that were associated with the passage of hurricanes Jose and Maria (2017) and Florence (2018) through the Hatteras region (Figure 12a, vertical lines). Hurricane Chris (2018) was not associated with an export event (Figure 12a). At other times, cross-shore transport of MAB shelf waters is near zero; the winter of 2017-2018 is a particularly stark example when multiple occupations of the slope transect included no waters fresher than 34.5 (Figure 12a, open circles). We examine some of these events in more detail in section 3.4.2.

Examination of along-shore transport through the shelf transect near $37^{\circ} \mathrm{N}$ (Figure $12 \mathrm{~b}$ ) sheds some light on the variability in cross-shore transport through the slope transect (Figure 12a). We compute transport through the shelf transect as in equation (1), limiting the integration to the portion of the transect between longitudes $74^{\circ} 45^{\prime} \mathrm{W}$ and $74^{\circ} 36^{\prime} \mathrm{W}$ due to observation coverage (Figure 1d). Though the slope and shelf transects do not bound a closed control volume, the presence of the coastal boundary to the west, Diamond Shoals to the south, and typically poleward flow over the shelf and slope south of Cape Hatteras suggests 
that southward flow into the region through the shelf transect should predominantly exit the region through the slope transect. On average, $0.07 \mathrm{~Sv}$ of MAB shelf water flowed southward through the shelf transect; like the cross-shore transport through the slope transect, the standard deviation of MAB water transport through the shelf transect was comparable to the mean (Figure 12b, horizontal dashed line and shading). For comparison, Lentz (2008) estimates transport of all waters shoreward of the shelf break to decrease from $0.16 \mathrm{~Sv}$ near $38^{\circ} \mathrm{N}$ to $0.09 \mathrm{~Sv}$ near $36^{\circ} 15^{\prime} \mathrm{N}$.

Despite the southward mean transport, northward transport of MAB shelf waters through the shelf transect occurs nearly $20 \%$ of the time (Figure $12 \mathrm{~b}$, thick line). These flow reversals are at least in part attributable to changes in sign of the cross-shore density gradient in the region (Figure 11i), which we estimate by differencing time series from the mapped products near the northern end of the slope transect (Figure 11f) and from near the inshore edge of the shelf transect (Figure 11c). Vertically averaged over the upper $60 \mathrm{~m}$ of the water column, the time series of density gradient has a zero-lag correlation of -0.33 with the transport of all waters through the shelf transect (Figure 12b, thin line). This correlation is significant at the $95 \%$ level if the ratio of the record length to the 25-day time scale used for mapping is used to determine 27 degrees of freedom in the estimate; however, the significance level is reduced to $84 \%$ if the number of degrees of freedom is more conservatively taken to be 11 based on the number of local minima in the time series of MAB shelf water transport through the shelf transect. Unlike in the northern and central MAB, where the mean density increases offshore (e.g., Gawarkiewicz et al., 2018, their Figure 2), the shelfbreak front near $37^{\circ} \mathrm{N}$ is typically density compensated with a mean cross-frontal density difference averaged over the upper $60 \mathrm{~m}$ of $0.01 \mathrm{~kg} \mathrm{~m}^{-3}$. When scaled by the thermal expansion and saline contraction coefficients, the offshore temperature and salinity increases across the front largely compensate (Figures 11g and 11h), resulting in isopycnals that are nearly level in the cross-shore direction (e.g., Figures 3 and 7).

Large MAB shelf water export events tend to be associated with pulses of southward flow through the shelf transect, while northward flow through the shelf transect is associated with little or no export of MAB shelf water through the slope transect (Figure 12). The zero-lag correlation between transport of MAB shelf waters through the slope transect (Figure 12a, heavy line) and transport of those waters through the shelf transect (Figure 12b, heavy line) is -0.41 . This correlation is significant at the $98 \%$ level if 27 degrees of freedom are assumed and is significant at the $89 \%$ level if 11 degrees of freedom are assumed. Correlation between southward flow over the shelf and export across the shelf break is consistent with continuity applied to a control volume with flow only through northern and eastern boundaries defined by the shelf and slope transects, respectively.

Much of the mismatch in both the mean and variability of MAB water transport through the shelf and slope transects may be attributed to the export of MAB shelf waters that enter the Hatteras region shoreward of the well-observed portion of the shelf transect (approximately the 75-m isobath). For instance, Churchill and Gawarkiewicz (2012) show evidence from moored observations during winter-spring 1996 that waters with salinities less than 32 entered the Hatteras region shoreward of the $30-\mathrm{m}$ isobath at $36^{\circ} 40^{\prime} \mathrm{N}$ and were subsequently exported across the shelf break near $35^{\circ} 30^{\prime} \mathrm{N}$; such flow would be missed by our glider sampling along the shelf transect but would be captured along the slope transect. Perhaps relatedly, salinities averaged over the 5-15 $\mathrm{m}$ depth range along the slope transect between $35^{\circ} 45^{\prime} \mathrm{N}$ and $36^{\circ} \mathrm{N}$ (i.e., near the Gulf Stream) were less than the minimum value of 30.76 observed along the shelf transect on three occasions (26 May 2017, 12 to 16 September 2018, and 13 April 2019) with the lowest value being 29.96 in April 2019. Salinities elsewhere along the slope transect were never less than the minimum observed along the shelf transect.

3.4.2. Example Events

Having established that export of MAB waters from the continental shelf near Cape Hatteras is largely event-driven, we now consider several distinct events that were captured by the sustained glider sampling during PEACH. These events are chosen both because they represent extrema in the rates of MAB shelf water export and to highlight the diversity of export events in this dynamic region.

3.4.2.1. Hurricane-Driven Export (Fall 2017)

In September 2017, hurricanes Jose and Maria passed by the Hatteras region. Jose passed closest to the PEACH region on 19 September; Maria followed on 27 September. As noted above, the passage of these storms was associated with large export of MAB shelf water (Figure 12a). For the south-to-north glider occupation of the slope transect during 25 September to 2 October, offshore transport of MAB shelf waters was 1.7 $\mathrm{Sv}$, the second largest of all estimates from individual glider transects. Time series of winds from NDBC buoys on the MAB shelf from south of Cape Hatteras to near Hudson Canyon (Figure 13) show that both storms 

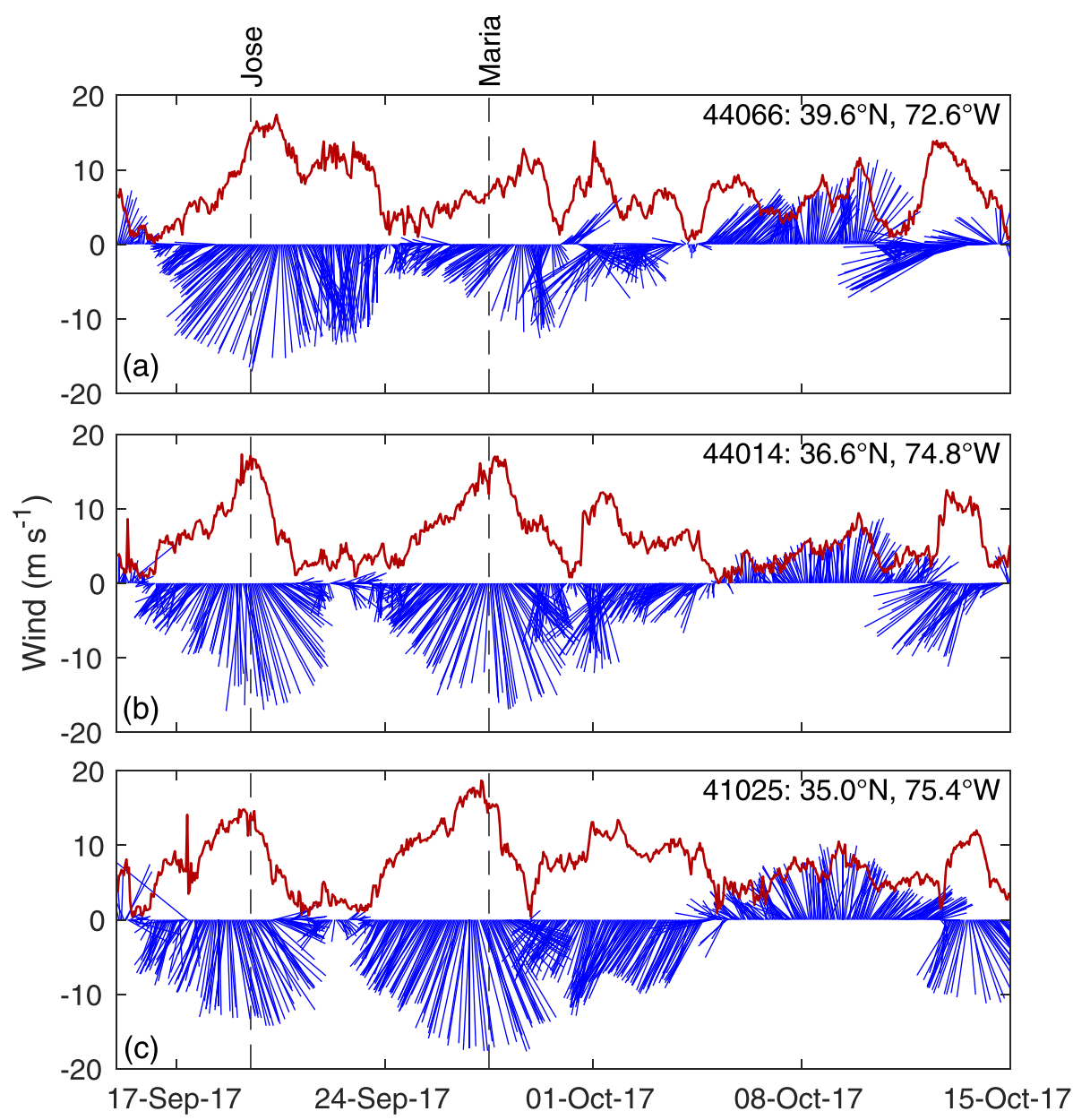

Figure 13. Winds during 15 September to 15 October 2017 as measured at three NDBC buoys over the outer continental shelf. (a) Buoy 44066 near Hudson Canyon, (b) buoy 44014 off Virginia Beach, and (c) buoy 41025 at Diamond Shoals. Hourly vectors (blue) show the direction toward which the wind was blowing; wind speed is shown in red. Dashed vertical lines indicate the times of closest approach of hurricanes Jose and Maria to the PEACH glider transect offshore of Oregon Inlet, NC (approximately $35^{\circ} 50^{\prime} \mathrm{N}$ ).

caused sustained southward (roughly along-shore) winds over most of the MAB for several days each with only a short break between storms. A sequence of SST images following passage of Jose (Figures 14a-14d) shows cool shelf waters being exported near Cape Hatteras and subsequent entrainment of those waters in the northeastward flow of the much warmer Gulf Stream. Glider observations collected just after Jose's passage and during Maria's passage (Figures 14e-14g) show that shelf waters fresher than 34.5 occupied most of the slope transect above about $120 \mathrm{~m}$ and north of about $35^{\circ} 40^{\prime} \mathrm{N}$. These shelf waters abutted the northern edge of the Gulf Stream, consistent with SST imagery, with little shelf water found beneath the warmer saltier Gulf Stream south of $35^{\circ} 40^{\prime} \mathrm{N}$. It seems likely that this large export of MAB shelf water in fall 2017 was a consequence of sustained along-shore winds from Hurricane Jose, which stalled offshore of the northern MAB after passing Cape Hatteras (see Todd et al., 2018), and Maria driving strong southward flow over the MAB shelf (Figure 12b).

\subsubsection{Cold Pool Export (Late Spring 2018)}

The largest export of MAB shelf water recorded during the 2-year PEACH glider campaign occurred in June 2018 (Figure 12a). The rate of shelf water export during a south-to-north glider transect reached 3.6 Sv and transport estimated from the gridded product exceeded 1.4 Sv. Unlike the storm-driven export in summer 2017, export during this event was primarily due to MAB Cold Pool waters being entrained beneath the northern edge of the Gulf Stream and rapidly carried offshore (Figure 15). In early June, Cold Pool waters, identifiable as a vertical minimum in temperature with salinity less than 34.5 , occupied most of the water column on the outer continental shelf, and an unusually strong shelfbreak jet carried both water and the glider 

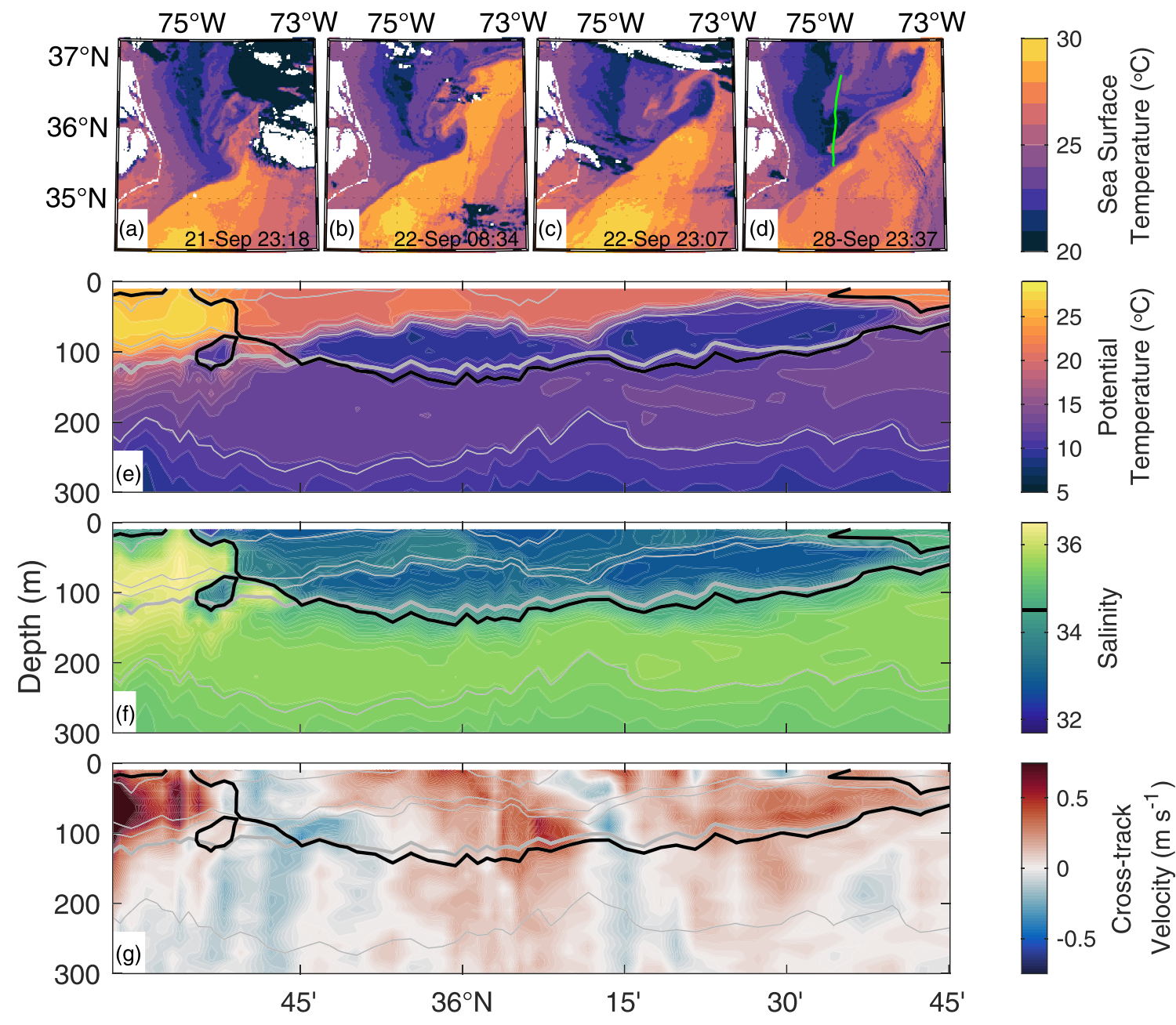

Figure 14. Export of MAB shelf water near Cape Hatteras in fall 2017 that was associated with passage of hurricanes Jose and Maria. (a-d) Sequence of SST images for the region showing progression of cooler MAB shelf waters offshore along the northern edge of the warmer Gulf Stream. (e-g) Observations of (e) potential temperature, (f) salinity, and (g) cross-track velocity in the upper $300 \mathrm{~m}$ from a south-to-north occupation of the slope transect during 25 September to 2 October 2017; the track of the glider is shown in (d). Gray contours are isopycnals, and the black contour is the 34.5 isohaline as in Figure 3. Transport of MAB water for this transect is shown with a star in Figure 12a.

southward (Figures 15a, 15b, and 15d). Cold Pool waters were then observed to be moving southeastward over the upper continental slope from $36^{\circ} 23^{\prime} \mathrm{N}$ to the edge of the Gulf Stream during 5-9 June (Figures 15f, $15 \mathrm{~h}$, and 15j). As the glider worked its way out of the Gulf Stream and back to the northern end of the slope transect during 10-19 June (Figure 15a), Cold Pool waters had subducted beneath the northern edge of the Gulf Stream and accelerated rapidly to the northeast (Figures 15g, 15i, and 15k). Subsequent reoccupation of the shelf transect during 20-22 June showed a less prominent Cold Pool and more typical current velocities, suggesting the end of this export event. Further investigation using other PEACH observing assets and numerical simulations is needed to identify the dynamics underlying this event. The subsuface nature of the export event made it undetectable by satellite or land-based remote sensing, highlighting the need for in situ observations to observe shelf water export.

\subsubsection{Cessation of Export (Winter 2017-2018)}

From early December 2017 through early March of 2018, transport of MAB shelf water through the slope transect essentially ceased (Figure 12a). Of 11 occupations of the slope transect between 6 December and 5 March, only two transects exhibited shelf water transport greater than 0.01 Sv; no MAB shelf water (salinity less than 34.5) was observed on seven slope transects during that time (Figure 12a, open circles). Given the multi-month duration of the near-cessation of MAB water export at the southern end of the MAB, we characterize the unusual hydrography and circulation by temporally averaging the gridded products along 

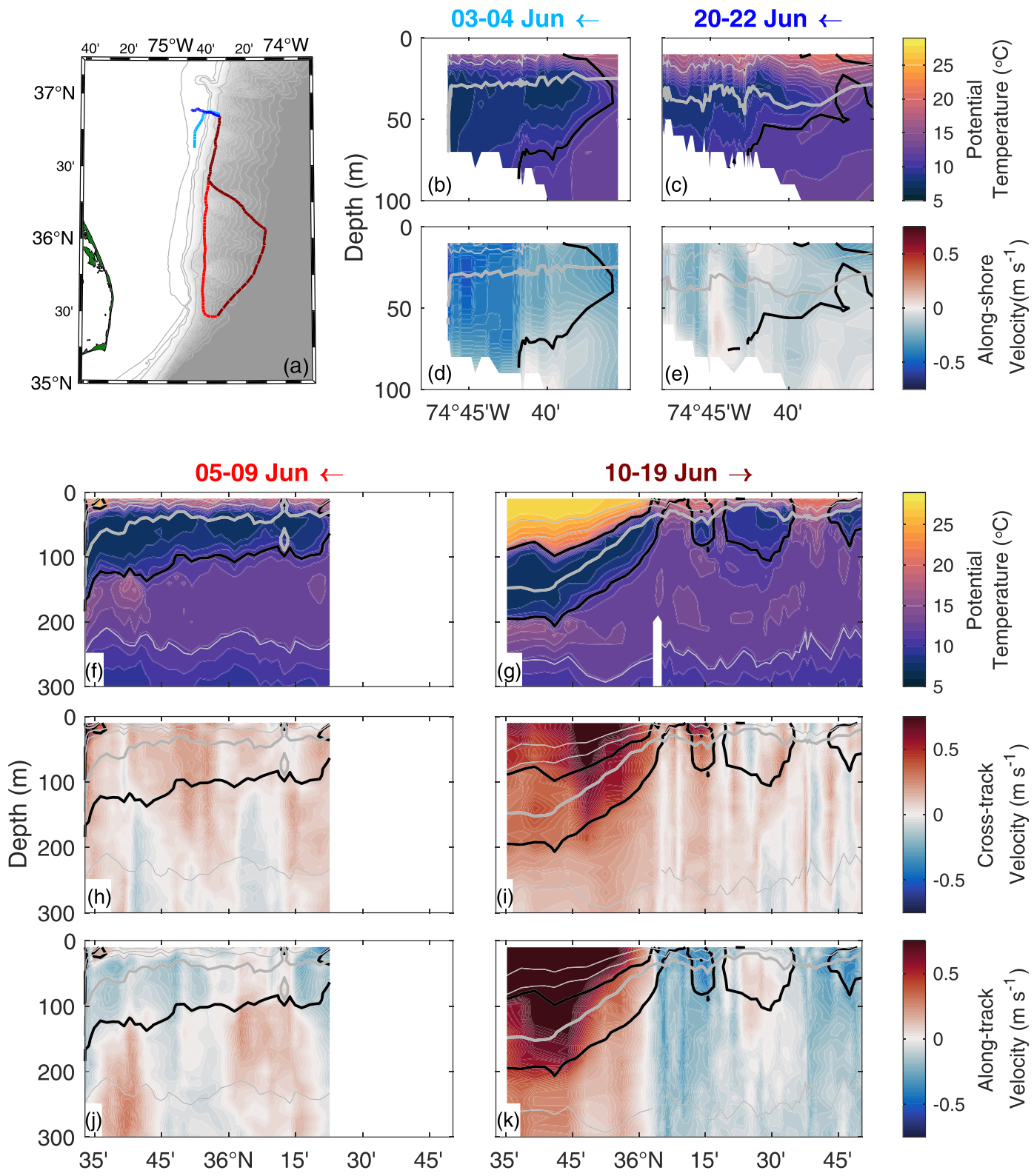

Figure 15. Entrainment of cool, fresh MAB Cold Pool waters beneath the warmer, saltier Gulf Stream. (a) Locations of sampling during 3-19 June 2018 with shelf transects in shades of blue and slope transects in shades of red. Dates and direction of glider motion for each transect are given in panels (b), (c), (f), and (g). Bathymetry is as in Figure 1b. (b-e) Potential temperature (b, c) and along-shore velocity (d, e) from occupations of the shelf transect during 3-4 June (b, d) and 20-22 June (c,e). (f-k) Potential temperature (f, g), cross-track velocity (h, i), and along-track velocity (j, k) from back-to-back occupations of the slope transect during 5-9 June (f, h, j) and 10-19 June (g, i, k). Cross-track velocities are positive offshore and used for transport calculations; along-track velocities are positive northward. In (b-k), gray contours are isopycnals, and the black contour is the 34.5 isohaline as in Figure 3. Transport of MAB water through the slope transect during 10-19 June is shown with a star in Figure 12a.

the slope and shelf transects during the period 1 December 2017 to 1 March 2018 (Figure 16). Compared to the two-year means along the transects (Figure 7), waters above about $100 \mathrm{~m}$ along the slope and shelf transects were markedly saltier (Figures 16c and 16d), cross-shore flow along the slope was much weaker north of the Gulf Stream (Figure 16e), and the flow along the shelf break near $37^{\circ} \mathrm{N}$ was strongly northward instead of southward (Figure 16h). SST images from the time period (e.g., Figure 17) indicate the presence of a filament of warm waters extending northward along the outer continental shelf and upper continental slope from the northern edge of the Gulf Stream near $35^{\circ} 40^{\prime} \mathrm{N}$ to nearly $38^{\circ} \mathrm{N}$. This filament was composed 


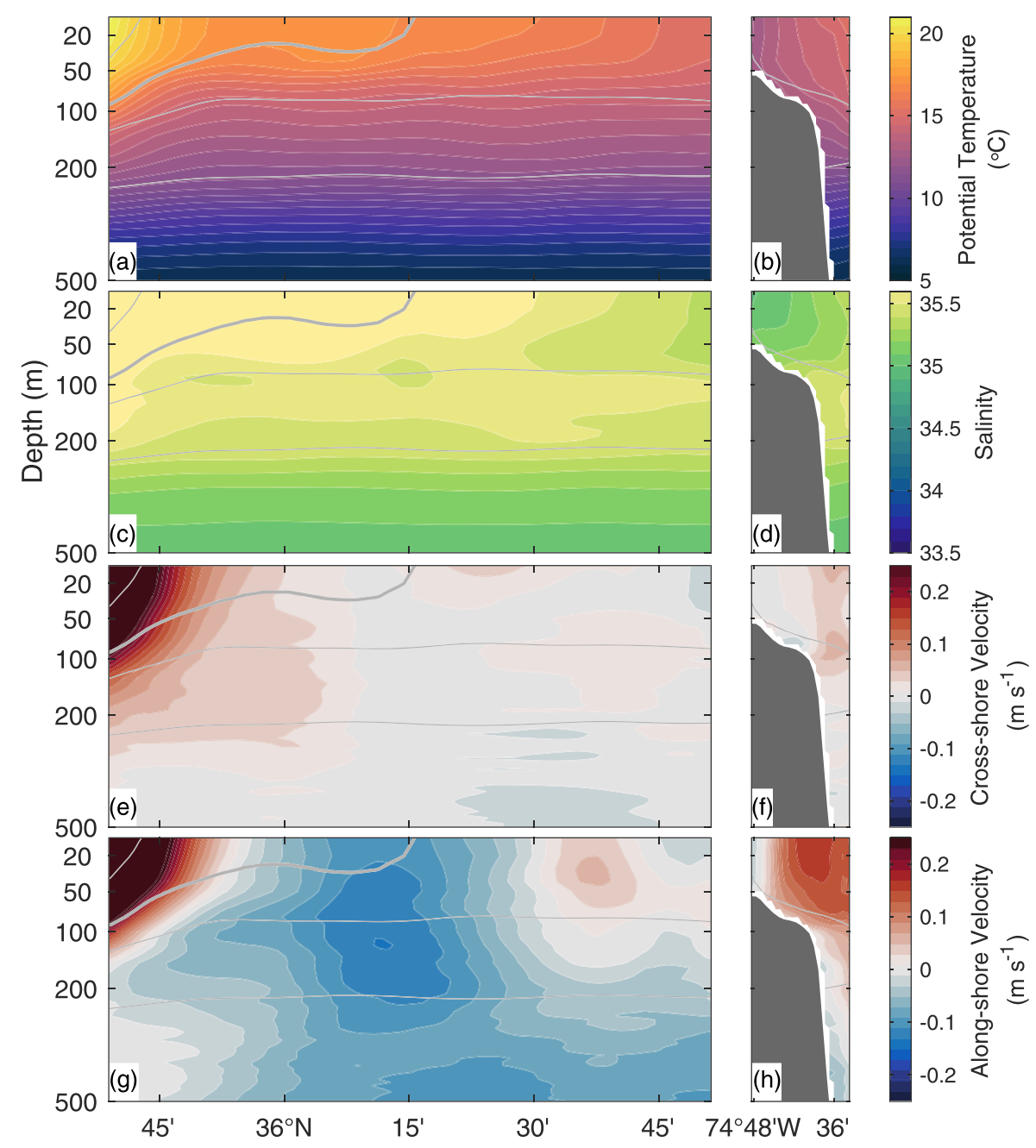

Figure 16. Time-averages of (a) potential temperature, (b) salinity, (c) cross-shore velocity, and (d) along-shore velocity during the period 1 December 2017 to 1 March 2018 when export of MAB waters largely ceased. Color limits are as in Figure 7 for comparison of this anomalous period to the two-year mean.

of waters that were less dense than adjacent shelf waters, so the resulting downward slope of isopycnals from shelf to deep water (Figure 16, right panels) supported northward geostrophic flow along the outer continental shelf (Figure 16h). Transport through the shelf transect was northward during most of the time period, except for a brief period in late January, and was predominately composed of waters saltier than 34.5 (Figure 12b). Though this was the only period during PEACH with such extensive intrusion of warm, salty waters along the outer shelf and upper slope (Figure 10), we note that Churchill and Cornillon (1991) documented several similar instances of Gulf Stream intrusions. They suggest that the density contrast between the Gulf Stream waters and adjacent slope waters to the northeast drives seaward transport of shelf waters at the northern extent of the Gulf Stream intrusion. If that was the case in the winter of 2017-2018, then we may expect that $\mathrm{MAB}$ shelf water was exported north of $38^{\circ} \mathrm{N}$, well beyond the range of PEACH observations.

\section{Summary}

For more than two years, autonomous underwater gliders collected sustained, high-resolution measurements along the upper continental slope and across the outer continental shelf to the north of the Gulf Stream's separation point at Cape Hatteras (Figure 1). These observations are novel in the Hatteras region because of their combined horizontal resolution, spatial extent, and temporal duration, which allow them to capture the mean and variability of exchange between the continental shelf and deep ocean. Sustained 

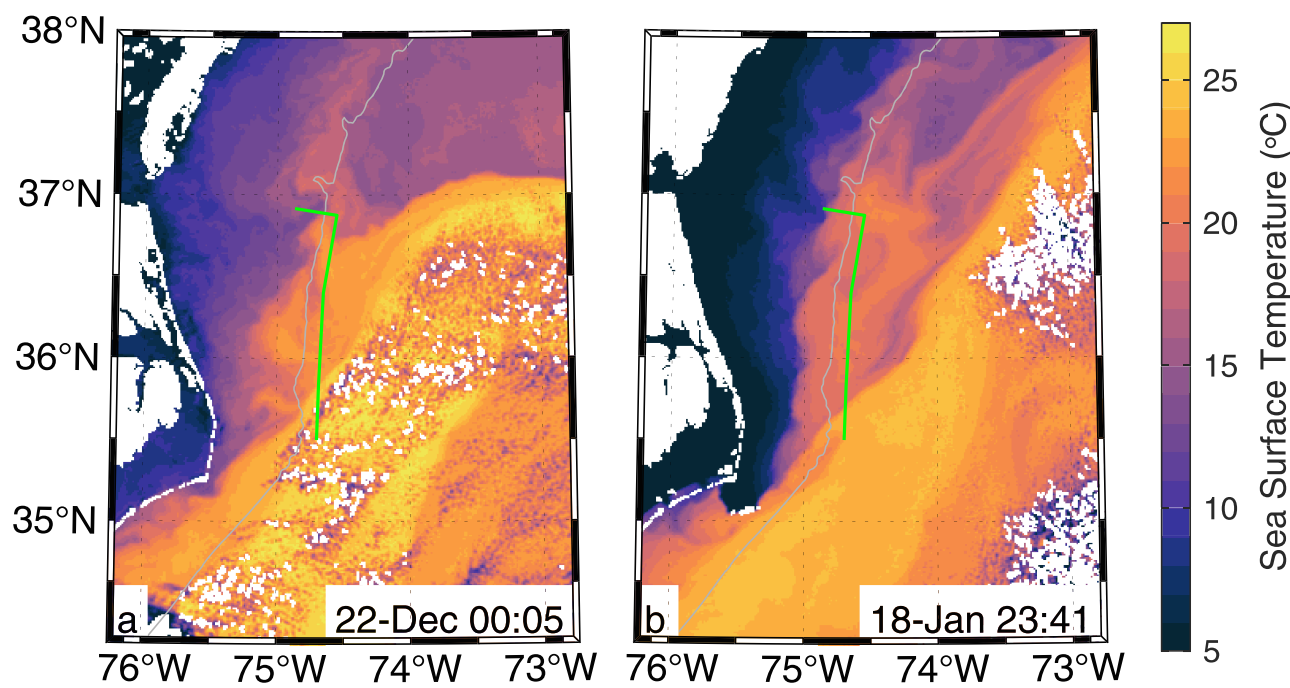

Figure 17. Sea surface temperature images from (a) 22 December 2017 and (b) 18 January 2018 during the period when export of MAB waters largely ceased. The nominal glider sampling track (green) and 200-m isobath (gray) are shown for reference.

glider operations during PEACH are a further demonstration of the central role of gliders in the ongoing development of observing networks for oceanic boundary current systems (Todd et al., 2019).

We estimate the time-mean and annual cycles of temperature, salinity, density, and horizontal velocity along two transects using least squares (Figures 7-9) and then objectively map anomalies from those fits to produce regularly gridded, low-pass-filtered products based on the glider observations (Figures 10 and 11). Though constructed from only two years of observations, the mean and annual cycles capture key features of the hydrography and circulation along the outer continental shelf and upper continental slope north of Cape Hatteras. Of particular note are the mean seaward flow (Figure 7e) and mean alongshore convergence (Figure $7 \mathrm{~g}$ ) measured along the slope transect, the phase lag between subsurface and surface temperature maxima due to advection of the MAB Cold Pool into the region (Figures 8a, 8b, 9a, and 9b), and arrival of the spring freshet in the northeastern portion of the survey region by mid-summer (Figures $8 \mathrm{c}$ and $9 \mathrm{c}$ ). The low-pass-filtered and gridded fields along the shelf and slope transects (Figures 10 and 11 and Movie S1) capture variability at timescales longer than 25 days and spatial scales larger than $30 \mathrm{~km}$ in the along-shore direction and $10 \mathrm{~km}$ in the cross-shore direction and can be sampled at arbitrary locations and times for various analyses.

Combining observations along individual glider transects and the gridded products, we demonstrate that export of MAB shelf waters across the continental shelf break near Cape Hatteras is largely event-driven (Figure 12a). Time mean transport of MAB shelf waters with salinities less than 34.5 across the slope transect was $0.3 \mathrm{~Sv}$, but half of the total export during more than two years of PEACH sampling occurred during the $17 \%$ of the time when MAB shelf water transport exceeded the mean by more than one standard deviation (i.e., transport exceeding $0.6 \mathrm{~Sv}$ ). These export events preferentially occurred during late spring and summer when equatorward flow into the region was strongest (Figure 8). MAB shelf water export was minimal during both winters sampled (Figure 12a). Export of MAB shelf water across the slope transect was correlated with along-shore transport through the shelf transect, which was itself somewhat correlated with the cross-shore density gradient across the outer continental shelf and slope. It follows that fluctuations in MAB shelf water export are at least in part driven by changes in the properties across the MAB shelfbreak front and resulting changes in along-shore geostrophic flow into the Hatteras region. The shelfbreak front itself is, on average, nearly density compensated near $37^{\circ} \mathrm{N}$ (Figure 11i), so reversals of alongshore flow are common (Figure 12b).

We examine three particular time periods to demonstrate the variety of scenarios related to MAB shelf water export in the Hatteras region. In September and October 2017, persistent, strong, along-shore winds over the MAB that were associated with hurricanes Jose and Maria (Figure 13) drove MAB shelf waters southward and then offshore near the surface and adjacent to the northern edge of the Gulf Stream (Figure 14). In 
contrast, the largest export of MAB shelf waters observed by gliders during PEACH occurred during June 2018 when MAB waters were exported beneath the northern edge of the Gulf Stream (Figure 15); the reason for this large, subsurface export is not yet clear. During winter 2017-2018, export of MAB shelf waters south of $37^{\circ} \mathrm{N}$ essentially ceased (Figure 12a). During this time, a filament of warmer, saltier, and lighter waters from the Gulf Stream occupied the upper continental slope (Figures 16 and 17), reversing the cross-shore density gradients and driving poleward flow along the outer continental shelf.

Our focus here has been the observations of hydrography, circulation, and MAB shelf water export collected by Spray gliders surveying the upper continental slope and outer continental shelf during PEACH. There were, however, a variety of complementary observing tools deployed during PEACH, and realistic numerical simulations are underway for the PEACH region. Future analyses should combine the full suite of PEACH observations and numerical simulations to diagnose the dynamics of shelf-deep ocean exchange near Cape Hatteras. Building on the analyses presented here, future analyses should focus on determining how variable wind forcing, Gulf Stream variability, and seasonal changes in hydrography combine to produce the event-driven export of MAB shelf waters in the Hatteras region.

\section{Acknowledgments}

Patrick Deane at WHOI and the Instrument Development Group at the Scripps Institution of Oceanography were key to the success of the Spray glider operations. Mike Muglia, Trip Taylor, and Nick DeSimone at the East Carolina University Coastal Studies Institute (CSI) provided support for glider deployments and recoveries. WHOI Summer Student Fellow Devon Gaynes assisted with analysis related to 2017 hurricanes. Spray glider observations used here are available from http://spraydata.ucsd.edu and should be cited using the following DOIs: 10.21238/S8SPRAY2675 (Todd \& Owens, 2016) and 10.21238/S8SPRAY0880 (Todd, 2020). Buoy winds are available from the National Data Buoy Center (https:// www.ndbc.noaa.gov). SST imagery was obtained from the Mid-Atlantic Regional Association Coastal Ocean Observing System (MARACOOS) THREDDS server (http://tds. maracoos.org/thredds/ARCHIVE-SST. html). Automated Tropical Cyclone Forecast System data are available online (https://ftp.nhc.noaa.gov/atcf/). PEACH was funded by the National Science Foundation (OCE-1558521). Colormaps are from Thyng et al. (2016).

\section{References}

Andres, M., Muglia, M., Bahr, F., \& Bane, J. (2018). Continuous flow of Upper Labrador Sea Water around Cape Hatteras. Scientific Reports, 8(4494), 1-8. https://doi.org/10.1038/s41598-018-22758-z

Berger, T. J., Hamilton, P., Wayland, R. J., Blanton, J. O., Boicourt, W. C., Churchill, J. H., \& Watts, D. R. (1995). A physical oceanographic field program offshore of North Carolina, final synthesis report (OCS Study MMS 94-0047). New Orleans, LA: Miner. Manage. Serv., Gulf of Mex. OCS Reg., U.S. Dep. of the Inter.

Castelao, R., Schofield, O., Glenn, S., Chant, R., \& Kohut, J. (2008). Cross-shelf transport of freshwater on the New Jersey shelf. Journal of Geophysical Research: Oceans, 113, C07017. https://doi.org/10.1029/2007JC004241

Cenedese, C., Todd, R. E., Gawarkiewicz, G. G., Owens, W. B., \& Shcherbina, A. Y. (2013). Offshore transport of shelf waters through interaction of vortices with a shelfbreak current. Journal of Physical Oceanography, 43(5), 905-919. https://doi.org/10.1175/JPO-D-120150.1

Chapman, D. C., \& Beardsley, R. C. (1989). On the origin of shelf water in the Middle Atlantic Bight. Journal of Physical Oceanography, 19, 384-391.

Chen, Z., Curchitser, E., Chant, R., \& Kang, D. (2018). Seasonal variability of the Cold Pool over the Mid-Atlantic Bight continental shelf. Journal of Geophysical Research: Oceans, 123, 8203-8226. https://doi.org/10.1029/2018JC014148

Chen, K., He, R., Powell, B. S., Gawarkiewicz, G. G., Moore, A. M., \& Arango, H. G. (2014). Data assimilative modeling investigation of Gulf Stream Warm Core Ring interaction with continental shelf and slope ciruculation. Journal of Geophysical Research: Oceans, 119, 5968-5991. https://doi.org/10.1002/2014JC009898

Church, P. E. (1937). Temperatures of the western North Atlantic from thermograph records. Ass. Océanogr. Phys. Union Géod. Geophys. Int., 4, 1-32.

Churchill, J. H., \& Berger, T. J. (1998). Transport of Middle Atlantic Bight shelf water to the Gulf Stream near Cape Hatteras. Journal of Geophysical Research, 103(C13), 30,605-30,621. https://doi.org/10.1029/98JC01628

Churchill, J. H., \& Cornillon, P. C. (1991). Gulf Stream water on the shelf and upper slope north of Cape Hatteras. Continental Shelf Research, 11(5), 409-431. https://doi.org/10.1016/0278-4343(91)90051-7

Churchill, J. H., \& Gawarkiewicz, G. G. (2012). Pathways of shelf water export from the Hatteras shelf and slope. Journal of Geophysical Research, 117, C08023. https://doi.org/10.1029/2012JC007995

Churchill, J. H., \& Gawarkiewicz, G. G. (2014). Shelf water and chlorophyll export from the Hatteras slope and outer shelf. Journal of Geophysical Research: Oceans, 119, 4291-4304. https://doi.org/10.1002/2014JC009809

Csanady, G. T., \& Hamilton, P. (1988). Circulation of slopewater. Continental Shelf Research, 8(5-7), 656-624. https://doi.org/10.1016/ 0278-4343(88)90068-4

Dirks, R. A., Kuettner, J. P., \& Moore, J. A. (1988). Genesis of Atlantic Lows Experiment (GALE): An overview. Bulletin of the American Meteorological Society, 69, 148-160. https://doi.org/10.1175/1520-0477(1988)069<0148:GOALEA>2.0.CO;2

Fisher, A. Jr. (1972). Entrainment of shelf water by the Gulf Stream northeast of Cape Hatteras. Journal of Geophysical Research, 77(18), 3248-3255. https://doi.org/10.1029/JC077i018p03248

Flagg, C. N., Dunn, M., Wang, D.-P., Rossby, H. T., \& Benway, R. L. (2006). A study of the currents of the outer shelf and upper slope from a decade of shipboard ADCP observations in the Middle Atlantic Bight. Journal of Geophysical Research, 111, C06003. https://doi.org/ $10.1029 / 2005$ JC003116

Fleming, N. E. (2016). Seasonal and spatial variability in temperature, salinity and circulation of the Middle Atlantic Bight (Ph.D. Thesis). Doctoral dissertation, Rutgers, The State University of New Jersey. https://doi.org/10.7282/T3XW4N4M

Ford, W. L., Longard, J. R., \& Banks, R. E. (1952). On the nature, occurence and origin of cold low salinity water along the edge of the Gulf Stream. Journal of Marine Research, 11, 281-293.

Gawarkiewicz, G. G., Brink, K. H., Bahr, F., Beardsley, R. C., Caruso, M., \& Lynch, J. F. (2004). A large-amplitude meander of the shelfbreak front during summer south of New England: Observations from the Shelfbreak PRIMER experiment. Journal of Geophysical Research, 109, C03006. https://doi.org/10.1029/2002JC001468

Gawarkiewicz, G. G., Churchill, J. H., Bahr, F., Linder, C. A., \& Marquette, C. (2008). Shelfbreak frontal structure and processes north of Cape Hatteras in winter. Journal of Marine Research, 66, 775-799.

Gawarkiewicz, G. G., Ferdelman, T. G., Church, T. M., \& Luther, G. W. (1996). Shelfbreak frontal structure on the continental shelf north of Cape Hatteras. Continental Shelf Research, 16(14), 1751-1773. https://doi.org/10.1016/0278-4343(96)00014-3

Gawarkiewicz, G. G., \& Linder, C. A. (2006). Lagrangian flow patterns north of Cape Hatteras using near-surface drifters. Progress in Oceanography, 70, 181-195. https://doi.org/10.1016/j.pocean.2006.03.020

Gawarkiewicz, G. G., Todd, R. E., Zhang, W., Partida, J., Gangopadhyay, A., Monim, M.-U.-H., et al. (2018). The changing nature of shelf-break exchange revealed by the OOI Pioneer Array. Oceanography, 31(1), 60-70. https://doi.org/10.5670/oceanog.2018.110 
Glenn, S. M., Miles, T. N., Seroka, G. N., Xu, Y., Forney, R. K., Yu, F., et al. (2016). Stratified coastal ocean interactions with tropical cyclones. Nature Communications, 7(10887), 1-10.

He, R., Chen, K., Moore, T., \& Li, M. (2010). Mesoscale variations of sea surface temperature and ocean color patterns at the Mid-Atlantic Bight shelfbreak. Geophysical Research Letters, 37, L09607. https://doi.org/10.1029/2010GL042658

Houghton, R. W., Schlitz, R., Beardsley, R. C., Butman, B., \& Chamberlin, J. L. (1982). The Middle Atlantic Bight Cold Pool: Evolution of the temperature structure during summer 1979. Journal of Physical Oceanography, 12, 1019-1029.

Kupferman, S. L., \& Garfield, N. T. (1977). Transport of low-salinity water at the slope water-Gulf Stream boundary. Journal of Geophysical Research, 82(24), 3481-3486. https://doi.org/10.1029/JC082i024p03481

Lentz, S. J. (2008). Observations and a model of the mean circulation over the Middle Atlantic Bight continental shelf. Journal of Physical Oceanography, 38, 1203-1221. https://doi.org/10.1175/2007JPO3768.1

Lentz, S. J. (2017). Seasonal warming of the Middle Atlantic Bight Cold Pool. Journal of Geophysical Research: Oceans, 122, 941-954. https://doi.org/10.1002/2016JC012201

Linder, C. A., \& Gawarkiewicz, G. G. (1998). A climatology of the shelfbreak front in the Middle Atlantic Bight. Journal of Geophysical Research, 103(C9), 18,404-18,423. https://doi.org/10.1029/98JC01438

Moody, J. A., Butman, B., Beardsley, R. C., Brown, W. S., Daifuku, P., Irish, J. D., et al. (1984). Atlas of tidal elevation and current observations on the northeast American continental shelf and slope, U.S. Geological Survey Bulletin 1611: U. S. Geol. Surv.

Pickart, R. S., \& Smethie, W. M. (1993). How does the Deep Western Boundary Current cross the Gulf Stream?. Journal of Physical Oceanography, 23, 2602-2616.

Rudnick, D. L. (2016). Ocean research enabled by underwater gliders. Annual Review of Marine Science, 8, 519-541. https://doi.org/10. 1146/annurev-marine-122414-033913

Rudnick, D. L., \& Cole, S. T. (2011). On sampling the ocean using underwater gliders. Journal of Geophysical Research, 116, C08010. https://doi.org/10.1029/2010JC006849

Rudnick, D. L., Davis, R. E., \& Sherman, J. T. (2016). Spray underwater glider operations. Journal of Atmospheric and Oceanic Technology, 33(6), 1113-1122. https://doi.org/10.1175/JTECH-D-15-0252.1

Rudnick, D. L., Sherman, J. T., \& Wu, A. P. (2018). Depth-average velocity from Spray underwater gliders. Journal of Atmospheric and Oceanic Technology, 35, 1665-1673. https://doi.org/10.1175/JTECH-D-17-0200.1

Rudnick, D. L., Zaba, K. D., Todd, R. E., \& Davis, R. E. (2017). A climatology of the California Current System from a network of underwater gliders. Progress in Oceanography, 154, 64-106. https://doi.org/10.1016/j.pocean.2017.03.002

Sampson, C. R., \& Schrader, A. J. (2000). The Automated Tropical Cyclone Forecasting System (version 3.2). Bulletin of the American Meteorological Society, 81(6), 1231-1240. https://doi.org/10.1175/1520-0477(2000)081<1231:TATCFS>2.3.CO;2

Savidge, D. K., \& Austin, J. A. (2007). The Hatteras Front: August 2004 velocity and density structure. Journal of Geophysical Research, 112, C07006. https://doi.org/10.1029/2006JC003933

Savidge, D. K., Austin, J. A., \& Blanton, B. O. (2013). Variation in the Hatteras front density and velocity structure Part 2: Historical setting. Continental Shelf Research, 54, 106-116. https://doi.org/10.1016/j.csr.2012.11.006

Savidge, D. K., \& Bane, J. M. (2001). Wind and Gulf Stream influences on along-shelf transport and off-shelf export at Cape Hatteras, North Carolina. Journal of Geophysical Research, 106(C6), 11,505-11,527. https://doi.org/10.1029/2000JC000574

Sherman, J., Davis, R. E., Owens, W. B., \& Valdes, J. (2001). The autonomous underwater glider "Spray". IEEE Journal of Oceanic Engineering, 26(4), 437-446. https://doi.org/10.1109/48.972076

Testor, P., deYoung, B., Rudnick, D. L., Glenn, S., Hayes, D., Lee, C. M., et al. (2019). OceanGliders: A component of the integrated GOOS. Frontiers in Marine Science, 6, 422. https://doi.org/10.3389/fmars.2019.00422

Thyng, K. M., Greene, C. A., Hetland, R. D., Zimmerle, H. M., \& DiMarco, S. F. (2016). True colors of oceanography: Guidelines for effective and accurate colormap selection. Oceanography, 29(3), 9-13. https://doi.org/10.5670/oceanog.2016.66

Todd, R. E. (2017). High-frequency internal waves and thick bottom mixed layers observed by gliders in the Gulf Stream. Geophysical Research Letters, 44, 6316-6325. https://doi.org/10.1002/2017GL072580

Todd, R. E. (2020). Spray glider observations in support of PEACH [Data set]. https://doi.org/10.21238/S8SPRAY0880

Todd, R. E., Asher, T. G., Heiderich, J., Bane, J. M., \& Luettich, R. A. (2018). Transient response of the Gulf Stream to multiple hurricanes in 2017. Geophysical Research Letters, 45, 10,509-10,519. https://doi.org/10.1029/2018GL079180

Todd, R. E., Chavez, F. P., Clayton, S., Cravatte, S., Goes, M., Graco, M., et al. (2019). Global perspectives on observing ocean boundary current systems. Frontiers in Marine Science, 6, 423. https://doi.org/10.3389/fmars.2019.00423

Todd, R. E., Gawarkiewicz, G. G., \& Owens, W. B. (2013). Horizontal scales of variability over the Middle Atlantic Bight shelf break and continental rise from finescale observations. Journal of Physical Oceanography, 43(1), 222-230. https://doi.org/10.1175/JPO-D-12-099.1

Todd, R. E., \& Locke-Wynne, L. (2017). Underwater glider observations and the representation of western boundary currents in numerical models. Oceanography, 30(2), 88-89. https://doi.org/10.5670/oceanog.2017.225

Todd, R. E., \& Owens, W. B. (2016). Gliders in the Gulf Stream [Data set]. https://doi.org/10.21238/S8SPRAY2675

Todd, R. E., Rudnick, D. L., Sherman, J. T., Owens, W. B., \& George, L. (2017). Absolute velocity estimates from autonomous underwater gliders equipped with Doppler current profilers. Journal of Atmospheric and Oceanic Technology, 34(2), 309-333. https://doi.org/10.1175/ JTECH-D-16-0156.1

Verity, P. G., Bauer, J. E., Flagg, C. N., DeMaster, D. J., \& Repeta, D. J. (2002). The Ocean Margins Program: An interdisciplinary study of carbon sources, transformations, and sinks in a temperate continental margin system. Deep Sea Research Part II, 49, 4273-4295. https://doi.org/10.1016/S0967-0645(02)00120-0

Zhang, W. G., Gawarkiewicz, G. G., \& McGillicuddy Jr, D. J. (2011). Climatological mean circulation at the New England shelf break. Journal of Physical Oceanography, 41, 1874-1893. https://doi.org/10.1175/2011JPO4604.1 